\title{
Comparing Two Seized Drug Workflows for the Analysis of Synthetic Cannabinoids, Cathinones, and Opioids
}

\author{
Edward Sisco ${ }^{a}$, Amber Burns ${ }^{b}$, Elizabeth Schneider ${ }^{b}$, Charles R. Miller, IVc, Laurel Bobka ${ }^{c}$ \\ aNational Institute of Standards and Technology, Gaithersburg, MD \\ ${ }^{b}$ Maryland State Police Forensic Sciences Division, Pikesville, MD \\ 'Maryland State Police Forensic Sciences Division, Hagerstown, MD \\ edward.sisco@nist.gov
}

As the challenges faced by drug chemists continue to persist due to the presence of synthetic opioids, novel psychoactive substances, and other emerging drugs, laboratories are continuing to look for new analytical approaches or techniques to ease the burdens. These new solutions can range from simple changes in existing methods to better distinguish isomers to adoption and implementation of entirely new technologies for screening or confirmation. One barrier to making these transitions is lack of data to understand how, or even if, workflow changes will address the challenges. In this study, we attempt to compare, qualitatively and quantitatively, an existing analytical workflow for seized drug analysis to a new, experimental workflow to better understand the potential benefits and drawbacks. Using adjudicated and mock case samples containing synthetic cannabinoids, synthetic cathinones, and opioids, four forensic chemists were asked to analyze fifty samples using one of two workflows. The first was an existing workflow that employed color tests for screening alongside general purpose gas chromatography flame ionization detection (GC-FID) and general purpose gas chromatography mass spectrometry (GC-MS) analyses for confirmation. The second was an experimental workflow that combined direct analysis in real time mass spectrometry (DARTMS) for screening with class-specific (targeted) GC-MS methods for confirmation. At each step in the analysis scheme, chemists recorded the time required and as well as their interpretation of the results. Comparison of the workflows showed that screening by DART-MS required the same amount of time as color tests but yielded significantly more accurate, and specific, information. Confirmation using the general purpose GC-FID and GC-MS methods of the existing workflow required more than twice the amount of instrument time and data interpretation time while also presenting other analytical challenges that prevented compound confirmation in select samples. Use of targeted GC-MS methods simplified data interpretation, reduced consumption of reference materials, and addressed almost all the limitations of general purpose methods. While the experimental workflow is not yet validated for casework, this study shows how rethinking analytical workflows for seized drug analysis could greatly assist laboratories in reducing turnaround times, backlogs, and standards consumption. It also demonstrates the potential impact of being able to investigate workflow changes prior to implementation.

Keywords: Seized Drug Analysis; Analytical Workflow; Mass Spectrometry; DART-MS; GC-MS; Comparison 


\section{Highlights}

- A comparison of two seized drug workflows was completed, measuring time and data quality

- The study compared a currently implemented workflow to an experimental workflow

- Screening with DART-MS was found to produce more specific results in the same amount of time as color tests

- Targeted GC-MS analyses were found to greatly reduce standards consumption and instrument time 


\section{Introduction}

Backlogs and analytical challenges continue to be major bottlenecks for forensic seized drug analysis. The increased prevalence of synthetic opioids, novel psychoactive substances (NPSs), and other emerging drugs, coupled with increased case submissions has led to a climb in turnaround times and backlogs in recent years [1,2]. These novel compounds have also introduced a number of new analytical challenges so much so that over $80 \%$ of laboratories reported limited analytical tools as one of their major challenges [3]. Recent research efforts have focused on approaches to keep pace with the changing landscape, ensuring adequate standards are available, methodologies for differentiating isomeric or isobaric species, and tools for sensitive detection of small amounts of highly toxic compounds [4].

To address these challenges laboratories may seek out new analytical capabilities that complement or replace their existing toolkit. New capabilities can include modifications to existing technologies, such as the adoption of new gas chromatography mass spectrometry (GC-MS) methods [5], or implementation of completely new technologies, such as DART-MS [6,7] or Raman spectroscopy [8]. When implementing new approaches or technologies, laboratories must estimate the improvements of changing their workflow. Improvements can be measured in overall analysis time (throughput), ease of analysis, or ability to obtain high-quality screening data (accuracy and reliability). The upfront and recurring costs of the change along with time required for procurement, method development, validation, and training, must also be considered. Oftentimes, the decision to change must be made without being able to tangibly measure the potential benefits or drawbacks of shifts in workflow, due to time and resource constraints. In some forensic disciplines, such as DNA analysis, the efficacy of different workflows has been studied, providing ability to make data-driven decisions $[9,10]$.

In this study, two different analytical workflows for seized drug analysis were compared to measure differences in time, data quality, safety, and simplicity. The workflows were compared using mock and adjudicated samples containing synthetic cannabinoids, synthetic cathinones, and opioids. The samples were given to four different practicing forensic chemists who were asked to analyze all samples using one of two workflows. The first workflow modeled existing practices at the Maryland State Police Forensic Sciences Division (MSP-FSD) and employed a combination of color tests, general purpose gas chromatography flame ionization detection (GC-FID), and general purpose gas chromatography mass spectrometry (GC-MS). The second workflow was developed to address many of the known limitations in the first workflow by leveraging direct analysis in real time mass spectrometry (DART-MS) for screening coupled with GC-MS methods developed for the targeted analysis of different drug classes. This study yielded tangible data to allow for direct comparison of the two workflows and better understand how changes to the existing laboratory protocols influence data quality, turnaround times, and requirements on the chemists.

\section{Materials \& Methods}




\section{Study Design and Analytical Workflows}

For this study, the goal was to identify and quantify the differences in two analytical workflows for seized drug analysis, specifically targeting synthetic cannabinoids, synthetic cathinones, and opioids. To do this, 50 samples, (described in more detail in the next section) were created that span the range of complexities and compounds within the three drug classes that are commonly observed at MSP-FSD. A portion of each of the 50 samples was provided to four different chemists at MSP-FSD who were asked to analyze the samples using one of the two workflows - referred to hereafter as the existing workflow and the experimental workflow. Each chemist analyzed half of the samples using the existing workflow and the remaining half using the experimental workflow. To simplify the process of recording times, samples were batched into groups of five and chemists analyzed one batch at a time. For each step in the workflow, chemists recorded the amount of time required to prepare, analyze, and interpret the data for the batch of samples. Chemists were also asked to provide their interpretation of the results after each analysis as well as an overall result of the controlled substance(s) present in each sample.

Schematics of the existing and experimental workflows are provided in Figure 1. For the existing workflow, which reflects current procedures at MSP-FSD, a batch of samples was first screened using three color tests (Mayers, cobalt thiocyanate, Marquis [11]) to provide an indication of the type, or types, of compounds that may be present in the sample. Two separate methanolic extracts were then created for each sample, one for GC-FID analysis and the other for GC-MS analysis. Details regarding these methods are provided below. The resulting GC-FID data was used to compare retention times of compounds in the samples to known standards while the resulting GC-MS data was used to obtain mass spectra of compounds in a sample to compare to spectra of standards previously collected on the instrument. The methods used for GC-FID and GC-MS were general purpose methods designed to achieve reasonable detection of a wide range of controlled substances.

In the experimental workflow, screening was completed using direct analysis in real time mass spectrometry (DART-MS) and was chosen because it produces more information-rich results than most other commonly deployed screening tools. It can often provide a near-complete chemical profile of a mixture and can identify the specific compounds, or group of isomeric compounds, in a sample. To leverage the higher fidelity screening information, confirmation was completed using a suite of targeted GC-MS methods. The methods were created to maximize retention time differences of similar compounds to reduce the number of pairs of compounds that could not be differentiated. Individual methods were created for synthetic cannabinoids, synthetic cathinones, and opioids. To investigate an approach to reduce consumption of reference materials, all methods were retention-time locked (where the carrier gas flow rate is adjusted to maintain consistent retention times of a lock column over the column's lifespan). This allowed for the analysis of only the lock compound with each batch, eliminating the need to run individual standards which were required for GC-FID analysis. For samples that contained compounds in multiple classes (i.e., dibutylone and fentanyl), analysis by multiple targeted methods was required. In addition, samples that were found by 
DART-MS to contain no controlled substances were concentrated, through the addition of more powder to the solution, and re-analyzed by DART-MS. If the concentrated sample also returned a negative result, the sample was reported as no controlled substances and no further analysis was completed.

\section{Existing Workflow}

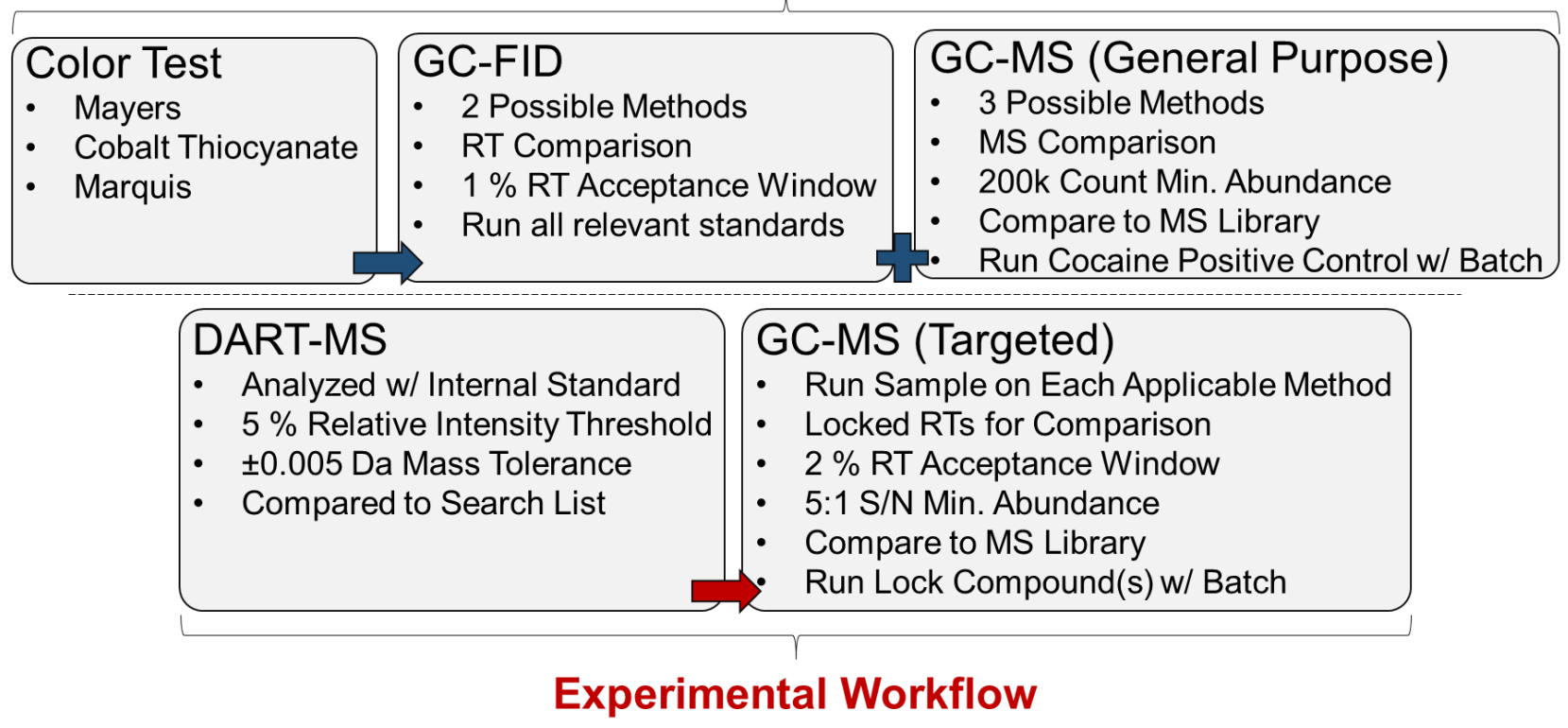

Figure 1. Schematic of the existing and experimental workflows.

\section{Case Samples}

For this study, a total of 50 samples were analyzed, the identities of which are provided in Table 1. Samples were created from either adjudicated case samples or standards purchased from Cayman Chemical (Ann Arbor, MI, USA) and Sigma-Aldrich (St. Louis, MO, USA). Samples were, largely, representative of commonly seen mixtures and ranged in complexity from simple, single compound samples to complex mixtures with drugs from multiple classes. Eight of the 50 samples contained no controlled substances. A total of 27 samples contained a single controlled substance, 10 contained two controlled substances ( 8 of which contained substances from multiple drug classes), and 5 contained three or more controlled substances. A total of 11 samples contained at least one synthetic cannabinoid, 19 samples contained at least one synthetic cathinone, and 22 samples contained at least one opioid. Once created, samples were divided into $2 \mathrm{~mL}$ GC-MS vials, each containing between $10 \mathrm{mg}$ and $50 \mathrm{mg}$ of powder. A set a vials was given to each chemist for analysis. Vials were labelled with only a number and the identity of the contents provided until the study was complete.

Table 1. List of the 50 samples used in this study. Non-controlled substances in the samples are also listed, in italics. Sample numbers with a dagger $\left({ }^{\dagger}\right)$ were created using one or more adjudicated case samples and sample numbers with an asterisk $\left(^{*}\right)$ were created using standards. Some samples were created using a mixture of both $\left({ }^{\dagger *}\right)$. Compound names with a double dagger $\left(^{\ddagger}\right)$ are compounds that, when previously analyzed, were found to be insufficient concentrations to allow for confirmation. 


\begin{tabular}{|c|c|c|c|}
\hline Sample & Contents & Sample & Contents \\
\hline $1^{\dagger}$ & $\begin{array}{l}\text { No Controlled Substance } \\
\text { Pill Binder }\end{array}$ & $26^{+}$ & $\begin{array}{l}\text { Eutylone } \\
\text { Caffeine }\end{array}$ \\
\hline $2^{\dagger}$ & Methamphetamine & $27^{*}$ & $\begin{array}{l}\text { No Controlled Substance } \\
\text { Caffeine }\end{array}$ \\
\hline $3^{\dagger}$ & $\begin{array}{c}\text { Heroin, MDMA } \\
\text { Mannitol, Quinine } \\
\end{array}$ & $28^{\dagger}$ & 4-Meththylethcathinone \\
\hline $4^{\dagger}$ & $\begin{array}{c}\text { Fentanyl, Tramadol }{ }^{\ddagger} \\
\text { Levamisole, Mannitol, } N \text { - } \\
\text { Phenylpropanamide, Procaine }\end{array}$ & $29^{\dagger *}$ & $\begin{array}{c}\text { 5-Fluoro-AKB48, } \alpha-P B P \\
\text { Mannitol }\end{array}$ \\
\hline $5^{\dagger}$ & $\begin{array}{c}\text { MPHP } \\
\text { Dextromethorphan }\end{array}$ & $30^{*}$ & Dibutylone, Fentanyl, JWH-250 \\
\hline $6^{\dagger}$ & MDMA & $31^{\dagger}$ & $\begin{array}{c}\text { Tramadol } \\
\text { Dextromethorphan }\end{array}$ \\
\hline $7^{\dagger}$ & $\begin{array}{c}\text { No Controlled Substance } \\
\text { Mannitol }\end{array}$ & $32^{\dagger}$ & JWH-250 \\
\hline $8^{\dagger}$ & $\begin{array}{l}\text { Heroin } \\
\text { Papaverine }\end{array}$ & $33^{\dagger}$ & $\begin{array}{c}\text { Fentanyl, Heroin, Acetyl Fentanyl }{ }^{\ddagger}, \\
\text { FIBF }^{\ddagger} \\
\text { Caffeine, Quinine }\end{array}$ \\
\hline $9^{\dagger}$ & Methyl Norfentanyl & $34^{\dagger}$ & Eutylone \\
\hline $10^{\dagger}$ & 4-Ethylmethcathinone & $35^{\dagger}$ & $\begin{array}{c}\text { Fentanyl, Tramadol }^{\ddagger} \\
\text { Caffeine, Levamisole, Mannitol, } N \text { - } \\
\text { Phenylpropanamide, Procaine }\end{array}$ \\
\hline $11^{\dagger *}$ & $\begin{array}{c}\text { Dibutylone } \\
\text { Caffeine }\end{array}$ & $36^{+}$ & Methyl-AP-237 \\
\hline $12^{\dagger *}$ & $\begin{array}{l}\text { 4-Ethylmethcathinone, Fentanyl, } \\
\text { 4-Me-a-ethylaminopentiophenone }\end{array}$ & $37^{\dagger}$ & Heroin \\
\hline $13^{\dagger}$ & FUB-AMB & $38^{\dagger}$ & JWH-250, a-Methyl Fentanyl \\
\hline $14^{\dagger}$ & $\begin{array}{c}\text { Cyclopropyl Fentanyl, Heroin, Phenyl } \\
\text { Fentanyl } \\
\text { Caffeine, Mannitol }\end{array}$ & $39^{\dagger}$ & $\begin{array}{c}\text { Fentanyl } \\
\text { Caffeine, Quinine, Xylazine }\end{array}$ \\
\hline $15^{\star}$ & $\begin{array}{l}\text { AB-FUBINACA 2-fluorobenzyl } \\
\text { isomer }\end{array}$ & $40^{\dagger *}$ & $\begin{array}{c}\text { 4-Chloroethcathinone, Cyclopropyl } \\
\text { Fentanyl }\end{array}$ \\
\hline $16^{\dagger}$ & $\begin{array}{l}\text { No Controlled Substance } \\
\text { Inorganic Compound }\end{array}$ & $41^{\dagger}$ & $\begin{array}{c}\text { No Controlled Substance } \\
\text { Mannitol }\end{array}$ \\
\hline $17^{\dagger}$ & Dibutylone & $42^{\dagger}$ & $\begin{array}{l}\text { Heroin, Acetyl Fentanyl }{ }^{\ddagger}, \text { Cocaine }^{\ddagger} \text {, } \\
\text { Fentanyl } l^{\ddagger}, \text { FIBFF}^{*}, \text { Noscapine }^{\ddagger} \\
\text { Caffeine, Quinine }\end{array}$ \\
\hline $18^{\dagger}$ & $\begin{array}{l}\text { Acetyl Fentanyl, Fentanyl } \\
\text { Mannitol, Quinine }\end{array}$ & $43^{\dagger}$ & Methylone \\
\hline $19^{\dagger}$ & $\begin{array}{c}\text { Heroin, Acetyl Fentanyl }\left.\right|^{\ddagger} \text {, Fentanyl }\left.\right|^{\ddagger} \text {, } \\
\text { FIBF }{ }^{\ddagger} \\
\text { Caffeine, Lidocaine, Mannitol, } \\
\text { Quinine }\end{array}$ & $44^{\dagger}$ & N-methyl Cyclopropyl norfentanyl \\
\hline $20^{*}$ & $\begin{array}{c}\text { No Controlled Substance } \\
\text { Guaifenesin, Quinine }\end{array}$ & $45^{*}$ & $\begin{array}{l}\text { No Controlled Substance } \\
\text { Lidocaine, Quinine }\end{array}$ \\
\hline $21^{*}$ & $\begin{array}{c}\text { No Controlled Substance } \\
\text { Acetaminophen, Citric Acid, Xylitol }\end{array}$ & $46^{\dagger}$ & 4-Methylethcathinone \\
\hline $22^{\dagger *}$ & Fentanyl, XLR11 & $47^{\dagger}$ & JWH-018, 3,4-MDPV \\
\hline $23^{\dagger}$ & JWH-250 & $48^{\dagger}$ & N-Ethyl Pentylone \\
\hline $24^{\dagger}$ & JWH-018 & $49^{*}$ & FUB-AMB \\
\hline $25^{\dagger}$ & $\alpha-P V P$ & $50^{\dagger *}$ & $\begin{array}{c}\alpha-P V P \\
\text { Sodium Bicarbonate }\end{array}$ \\
\hline
\end{tabular}




\section{Existing Workflow}

\section{Color Tests}

Three color tests were completed (Mayers, cobalt thiocyanate, and Marquis) in disposable well plates. To complete a test, several drops of the appropriate reagent(s) were added to the well followed by a small amount (several milligrams) of sample powder after which the color change, if any, was observed. In addition to noting the color changes that occurred, chemists were also asked to provide an interpretation of each result, and record the time it took to complete the entire process for every batch of five samples.

The Marquis reagent was created by combining $10 \mathrm{~mL}$ of $37 \%$ formaldehyde with $100 \mathrm{~mL}$ of concentrated sulfuric acid. Cobalt thiocyanate reagent was created by dissolving $6.0 \mathrm{~g}$ of cobalt thiocyanate in $240 \mathrm{~mL}$ of water mixed with $360 \mathrm{~mL}$ of $0.1 \mathrm{M}$ hydrochloric acid. The Mayer's reagent was created by dissolving 6.0 $\mathrm{g}$ of mercuric chloride in $600 \mathrm{~mL}$ of water followed by the addition of potassium iodide to dissolve the red precipitate.

\section{GC-FID}

GC-FID was employed to compare retention times of the controlled substances in the samples to reference materials. Analyses were completed on one of two Agilent GC systems (Agilent Technologies, Santa Clara, CA, USA) using methods that were validated for casework. Parameters for both methods are provided in Supplemental Table 1.

Samples were prepared by dissolving $1 \mathrm{mg}$ to $2 \mathrm{mg}$ of material into approximately $1.5 \mathrm{~mL}$ of methanol. The solution was shaken by hand for several seconds then allowed to sit for several minutes so any undissolved particulates could settle. The supernatant was then transferred to another GC vial for analysis.

All samples were analyzed with a single injection. Once compounds were preliminarily identified, reference materials (solutions containing known drugs) were analyzed using the same method to establish retention times for comparison. In addition to the suspected controlled substance, all isomers and similar compounds (compounds that have similar retention times) were also run. For each batch, reference materials were only run once, even if they were required for multiple samples. A list of reference materials run for each of the controlled substances in the study is provided as Supplemental Table 2. For a positive identification of a substance, the retention times of the sample and the reference material needed to be within $\pm 1 \%$ of one another and none of the other required reference materials, if applicable, had retention times within $\pm 1 \%$ of the sample. Overall identification of a substance required a positive identification from the GC-FID data and the GC-MS data, discussed in the next section.

\section{GC-MS (General Purpose)}

General purpose GC-MS was the second component of the confirmation process and was used to compare mass spectra from compounds in samples to those previously collected from reference materials. Analysis 
was completed on one of two Agilent GC-MS systems. There were three casework validated methods that chemists could use depending on which laboratory they were in as well as their preference and the suspected compounds in the sample. Method parameters for the three methods are provided in Supplemental Table 3. Sample preparation for GC-MS was identical to GC-FID.

All samples were analyzed as a single injection. A cocaine positive control was run with each batch of samples for each method used. After analysis, all peaks in the chromatogram were searched against mass spectral libraries created in house, as well as the SWGDRUG library. Positive identification criteria included having an abundance of 200,000 counts or greater in the chromatogram along with an acceptable mass spectral match to a library entry. If any of these criteria were not met, or the GC-FID criteria were not met, an "insufficient" finding was made.

\section{Experimental Workflow}

\section{DART-MS}

Sample screening using the experimental workflow was completed using DART-MS. The protocols used here have been discussed in detail elsewhere [12]. Briefly, samples were prepared by dissolving approximately $1 \mathrm{mg}$ of material into $1 \mathrm{~mL}$ of methanol containing tetracaine as an internal standard. Data was collected using a sequence-based approach with individual, 1 min data files collected for each sample. Within the 1 min datafile, the internal standard solution was analyzed once by itself followed by three analyses of the sample combined with the internal standard. All analyses were completed by dipping a clean glass microcapillary into the solution and placing it in the open-air sampling region. Measurements were made on one of two systems using identical methods. The systems consisted of DART-SVP ion sources (IonSense, Saugus, MA, USA) coupled to JEOL AccuTOF 4G-LCplus mass spectrometers (JEOL USA, Peabody, MA, USA). Helium was used as the DART gas source with a gas stream temperature of $400{ }^{\circ} \mathrm{C}$ and operation in positive ionization mode. The mass spectrometer was also operated in positive ionization mode with an orifice 1 voltage of $+30 \mathrm{~V}$, a ring lens voltage of $+5 \mathrm{~V}$, an orifice 2 voltage of $+5 \mathrm{~V}$, and an ion guide voltage of $+800 \mathrm{~V}$. Spectra were collected from $\mathrm{m} / \mathrm{z} 80$ to $\mathrm{m} / \mathrm{z} 800$ at a rate of $0.4 \mathrm{~s} / \mathrm{scan}$. Upon completion of the sequence, the datafiles were automatically mass drift compensated using the $\mathrm{m} / \mathrm{z}$ value for the protonated molecule of tetracaine (the internal standard). For each sample, an averaged mass spectrum of the three analyses was extracted, background subtracted, and saved as a centroided datafile. The centroided spectra were then analyzed using the "Search From List" feature within Mass Mountaineer (Diablo Analytical, Antioch, CA, USA) using an in-house created search list containing information for over 600 compounds of interest to seized drug analysis. Search parameters for peak identification included a minimum peak height threshold of $5 \%$ relative abundance and a maximum $\mathrm{m} / \mathrm{z}$ drift of $\pm 0.005 \mathrm{Da}(5 \mathrm{mDa})$ which was based on the mass tolerance of the instrument. For instances where multiple compounds produce the same $\mathrm{m} / \mathrm{z}$ value, fragment ions were used to differentiate compounds, if possible. The tetracaine internal standard was used as a quality control compound, where the presence and correct $\mathrm{m} / \mathrm{z}$ 
value of the protonated molecule was required for a datafile to be used. The time required to analyze every batch of five samples was also noted.

\section{GC-MS (Targeted Analysis)}

Confirmation was completed using a suite of targeted GC-MS methods. Preparation of samples was identical to that for the GC-FID and GC-MS methods described in the existing workflow above. The targeted methods were created using a previously published framework [5] and were developed for each of the three compound classes investigated. Discussion on the development of the targeted methods is provided elsewhere [5,13], and the actual instrument methods are provided in Supplemental Table 4. All analyses were completed using an Agilent 7890/5977B GC-MS with helium as the carrier gas. The targeted methods were developed to maximize retention time differences between similar compounds within a reasonable runtime in order to minimize the number of compound pairs with overlapping retention time acceptance windows. The methods employed retention time locking to decrease consumption of reference materials. Using this approach, prior to running a batch of samples, the method was re-locked by analyzing the lock compound. A positive control was run with the batch of samples to confirm the locking was successful. If a sample contained compounds from multiple classes, repeat analyses were completed for all appropriate targeted methods.

After analysis, the resulting data was interpreted by comparing both the retention time and the mass spectra for all peaks within a chromatogram. A retention time acceptance window of $\pm 2 \%$ for all methods and a \pm 1 $\%$ window for the retention time agreement of the lock compounds were used. A positive identification was defined as a chromatographic peak with a signal to noise ratio greater than $5: 1$ within the $\pm 2 \%$ acceptance window of the previously run reference material and with a minimum mass spectral match factor of 85 a.u. when compared to mass spectral libraries created in house or provided in the SWGDRUG Library (v 3.6).

\section{Results \& Discussion}

\section{Comparison of Color Test to DART-MS for Compound Screening}

Analysis of the 50 samples by four examiners produced a total of 100 results per workflow to compare while also providing two independent analyses of each sample on each workflow. Comparison of the two screening techniques initially proved to be difficult because of the lack of comparable data. To address this challenge, a scoring system, outlined in Table 2, was created. Scores ranged from - 1 to 4 and attempted to capture both the accuracy and specificity of the result, with more accurate and specific results receiving higher scores. For DART-MS, the result was the identified compound(s) that met the identification criteria. For color tests, the result was the chemists' interpretation of the color changes that occurred based on their expert knowledge and prior experience. If the result was inconsistent with the actual contents of the sample, a score of -1 was given. If the result was inconclusive (i.e. it could not be determined whether or not a controlled substance was present in the sample), a score of 0 was given. For results that were consistent with the contents of the sample, positive scores were given. A score of 1 was given to results that were 
accurate but the least specific, defined as those where only a class identification (i.e. the sample contains an opioid, synthetic cannabinoid, etc.) was possible for at least one of the controlled substances in the mixture. The next level of specificity was defined as the sub-class (i.e. fentanyl) or isomer group (i.e. ABFUBINACA or one of its isomers). If the sub-class was identified for at least one controlled substance in a sample with multiple controlled substances, a score of 2 was given. A score of 3 was given if the sub-group was correctly identified for a sample containing a single controlled substance or for a sample where the sub-class or isomer group was correctly identified for all compounds in a sample containing multiple controlled substances. The most specific level of information was identification of the specific compound, which was given a score of 4 . For samples containing multiple controlled substances, all controlled substances needed to be identified to obtain a score of 4 . A score of 4 was also given when a sample that did not contain any controlled substances produced a result consistent with the absence of controlled substances.

Table 2. Scoring system used to rank the colorimetric and DART-MS screening results.

\begin{tabular}{|c|c|}
\hline Score & Outcome \\
\hline-1 & Identification of compound or compound class that is inconsistent with actual contents \\
\hline 0 & Inconclusive Result \\
\hline 1 & Correct identification of compound class for at least one compound \\
\hline 2 & $\begin{array}{r}\text { Correct identification of at least the sub-class or isomer group identified for at least one } \\
\text { compound (mixtures only) }\end{array}$ \\
\hline 3 & Correct identification of at least the sub-class or isomer group for all compounds \\
\hline 4 & $\begin{array}{r}\text { Correct identification of all compounds identified OR correct identification of a negative } \\
\text { sample as negative for controlled substances }\end{array}$ \\
\hline
\end{tabular}

This system was used to score all colorimetric and DART-MS results obtained by each of the four chemists. A complete list of scores is provided in the Supplemental Table 5 while the summary results are provided in Figure 2. As expected, DART-MS was able to provide a more complete chemical profile of the samples resulting in both more accurate and more specific results. The average score for DART-MS was $3.4( \pm 0.6)$ compared to $1.2( \pm 1.6)$ for color tests. This was not surprising since color tests usually only provide classlevel information whereas DART-MS can provide more specific information in nearly all instances. Out of all the DART-MS results, only two samples [heroin and MDMA (Sample 3) and heroin, with an indication of fentanyl, acetyl fentanyl, FIBF, cocaine, and noscapine (Sample 42)] failed to produce isomer group or compound identifications for all components in the sample. These missed identifications were the result of the concentrations of the compounds in the sample being below the detection limit of the technique, resulting in a score of 2 . 


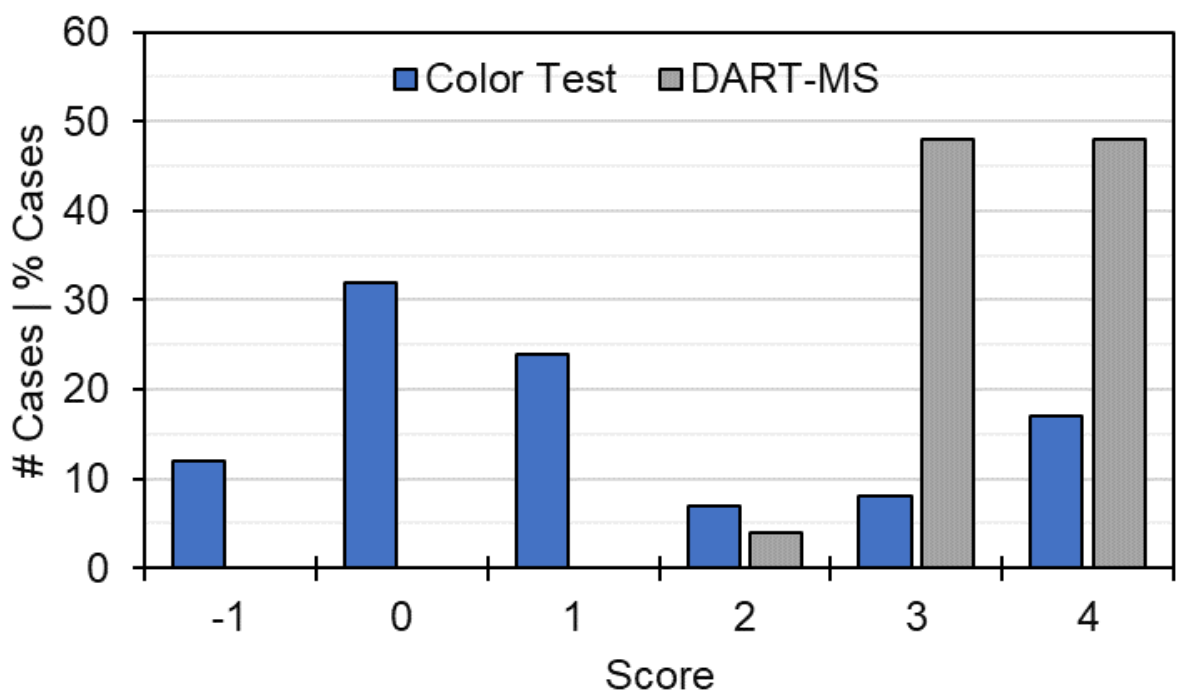

Figure 2. Histogram showing the distribution of scores for the color test results (blue, $n=100$ ) and the DART-MS results (grey, $n=100$ ).

The poor specificity and irreproducibility of the color tests results for this set of samples was unexpected. Color tests produced an inconclusive result nearly one third $(n=32)$ of the time and produced an inconsistent result on twelve separate occasions. Additionally, $18 \%$ of the samples produced differing results when analyzed by the two chemists, resulting in different scores for the same sample. It is unclear what the driver of this observation was, but it may have been due to heterogeneric samples. The twelve inconsistent results (score $=-1$ ) were spread across eight samples, four samples where both chemists had inconsistent results and four sample where only one chemist had an inconsistent result. Of the three samples where the color test produced results that led to an inconsistent identification by both chemists, two were samples without a controlled substance that contained significant fractions of quinine (Samples 20 and 45). These samples both produced responses consistent with the presence of heroin or another opiate. The third instance was a sample which contained JWH-018 but elicited a response consistent with a cathinone (Sample 24) and the fourth was a sample containing tramadol that produced a response consistent with a fentanyl (Sample 31). The four samples where one chemist got an inconsistent result included two instances where a synthetic cathinone produced a response consistent with a fentanyl (Samples 28 and 5), one instance where a methamphetamine response resulted from a sample containing a cathinone and fentanyl (Sample 12), and one instance where a heroin response resulted from a sample containing fentanyl (Sample 39).

For DART-MS, consistent results across chemists were obtained in all instances, except for Sample 42 where only one of the two chemists were able to detect low levels of FIBF and noscapine. There were no instances of a false positive or false negative identification. As expected, there were many instances where DART-MS produced only sub-class or isomer group information because of the fact isomeric compounds have identical base peaks and often have similar fragment ions. Given the lack of chromatographic 
separation, DART-MS is unable to differentiate these compounds from one another. When sub-class or isomer group information was obtained, it frequently consisted of a narrow of candidate compounds (five or fewer), though for the cathinones, the sub-class list (i.e. Cathinone at $\mathrm{m} / \mathrm{z} 192$ ) can encompass more than ten compounds. Given DART-MS is being used as a screening tool, this is not an issue as the chemist now has confidence in the type and class of compound(s) present in the sample. Chemists should be aware, however, that low-level compounds, especially those with low proton affinity, may be missed in a DARTMS analysis because of competitive ionization, as was the case in Samples 3 and 42, where heroin was not identified above $5 \%$ relative intensity.

DART-MS was able to correctly identify all eight of the samples that did not contain controlled substances as negative while color tests produced two false positives (discussed above) along with a single inconclusive result for one chemist (Sample 41). Confirmation of negative samples by DART-MS, completed by analyzing a concentrated sample, did not introduce any complications or produce any measurable signatures of carryover or contamination. The use of the internal standard eliminated the potential of false positive identification of noise peaks in spectra from samples that do not contain controlled substances or other easily desorbed and ionized species by providing a substantial base peak in all spectra. The lack of a base peak leading to false positive identification of noise peaks (because peak searching above a relative intensity threshold is often employed) is a common limitation in spectra that do not contain controlled substances.

In addition to establishing the differences in accuracy and specificity produced by these two techniques, the time required for analysis was also measured. For both techniques, the time required for sample preparation, sample analysis, and data interpretation (for DART-MS), was noted by the chemists for each batch of five samples. For color tests, the average time per batch was $18.6 \mathrm{~min}$ while for DART-MS it was $20 \mathrm{~min}$. This DART-MS analysis time was split up, roughly, as 5 min for sample preparation, 2 min for sequence preparation, $5 \mathrm{~min}$ for analysis of samples, and $8 \mathrm{~min}$ for data workup. In terms of sample consumption, color tests typically required more sample for analysis (approximately $5 \mathrm{mg}$ versus $1 \mathrm{mg}$ to 2 $\mathrm{mg}$ for DART-MS); though for most samples this difference would be negligible. From a potential exposure viewpoint, DART-MS presented a lower overall risk as handling of bulk powder is limited to only one transfer of material, unlike color tests which require multiple transfers of material. DART-MS only requires methanol to dissolve the sample, while color tests require the use of other, more hazardous, chemicals like formaldehyde and concentrated acids.

While DART-MS provides a more information-rich, more accurate, possibly safer, analysis in roughly the same amount of time as color tests, it does require a large upfront investment in the technology which could present a barrier for adoption. However, color tests were found to be inconsistent and prone to differing results given the set of samples tested. The lack of class or compound specific results and the high frequency of inconclusive results obtained using color tests indicates that this approach would be ill-suited for inclusion in a workflow that utilized targeted or class-specific confirmation methods. The ability to obtain 
more granular and correct compound information from DART-MS is critical for use of targeted or classspecific confirmation methods. The benefits of DART-MS are not specific to the experimental workflow investigated here and can be realized when used alongside general purpose confirmation methods as well.

\section{Comparison of General GC-MS and GC-FID to Targeted GC-MS}

Because the technique used for confirmation in both workflows was identical, comparison of results was simplified. Overall, as expected, the results obtained from the existing workflow and the experimental workflow were largely similar. Because of differences in confirmation criteria between the two approaches, there were some differences regarding which compounds could be confirmed versus which compounds were identified but produced data that was insufficient for confirmation. Table 3 shows the summary of results obtained for the two workflows. Both workflows were found to have analytical limitations which presented as insufficient identifications. The existing workflow had ten samples with insufficient identifications while the experimental workflow had three samples. Insufficient identifications were caused by several factors including low chromatographic peak intensity, co-elution, and lack of inclusion on target compound panels.

For the existing workflow, using general purpose GC-FID and GC-MS methods, there were several samples that had co-eluting peaks - namely acetyl fentanyl and FIBF - which precluded the ability to confirm either when both were present in the sample. These two compounds were not sufficiently separated on the GCFID method and did not provide sufficient separation to obtain clean mass spectra with the general purpose GC-MS methods. With the experimental workflow that used a targeted method developed specifically for opioid analysis detection and separation of these two compounds was readily achieved. An example of this is shown in Figure 3 for Sample 19. In addition to this, there was one sample (Sample 35) where co-elution of tramadol and mannitol precluded confirmation of tramadol for both workflows.

Another limitation with the existing workflow was the inability to confirm dibutylone. When analyzing dibutylone on both GC-FID and GC-MS, there were other isomeric compounds that eluted well within the $\pm 1 \%$ retention time window of dibutylone and had mass spectra that were too similar to allow for differentiation. Using the targeted methods in the experimental workflow, however, provided sufficient separation to allow for confirmation of dibutylone. The general purpose GC-MS methods in the existing workflow use a minimum of 200,000 count peak abundance in the chromatogram for confirmation which lead to inability to confirm the identifies of compounds in seven samples (resulting in an insufficient identification). This limitation could be addressed by concentrating the sample, though care must be taken to ensure the major components in the sample do not saturate the detector.

For the targeted method approach, there were two instances (Sample 2 and Sample 42) where controlled substances were present in the sample that were not part of the panels for any of the targeted methods and therefore could not be confirmed. While this resulting in incomplete confirmation of all substances in these two samples, it can be addressed by simply adding additional compounds to the panel(s). This 
process does require some time due to the need to complete replicate measurements of standards but is straightforward. This also highlights the potential need for a catch-all method that incorporates compounds outside of the classes that have targeted methods.

Table 3. Summary results for the confirmatory analysis of the fifty samples using the existing and experimental workflows. Only controlled substances are listed. Compounds that were detected but could not be confirmed are listed as insufficient, and the reason for the insufficient designation is provided. A double dagger $\left(^{\ddagger}\right)$ indicates that the compound was not at a high enough abundance in the GC-MS chromatogram for confirmation, a superscript RT (RT) indicates that there were multiple similar compounds with overlapping retention time windows which precluded confirmation, and compounds in parentheses indicate instances where co-elution precluded confirmation. A breakdown of these results is shown in Supplemental Table 6 and Supplemental Table 7.

\begin{tabular}{|c|c|c|}
\hline Sample & Existing Workflow Results & Experimental Workflow Results \\
\hline 1 & No Controlled Substances & Not Analyzed \\
\hline 2 & Methamphetamine & $\begin{array}{l}\text { Methamphetamine Not Confirmed } \\
\text { (Not in Targeted Methods) }\end{array}$ \\
\hline 3 & $\begin{array}{c}\text { MDMA } \\
\text { Insufficient: Heroin }\end{array}$ & Heroin, MDMA \\
\hline 4 & $\begin{array}{c}\text { Fentanyl } \\
\text { Insufficient: Tramado/ }\end{array}$ & $\begin{array}{c}\text { Fentanyl } \\
\text { Insufficient: (Tramadol / Mannitol) }\end{array}$ \\
\hline 5 & MPHP & MPHP \\
\hline 6 & MDMA & MDMA \\
\hline 7 & No Controlled Substances & Not Analyzed \\
\hline 8 & Heroin & Heroin \\
\hline 9 & N-Methyl Norfentanyl & N-Methyl Norfentanyl \\
\hline 10 & 4-Ethylmethcathinone & 4-Ethylmethcathinone \\
\hline 11 & Insufficient: Dibutylone $e^{R T}$ & Dibutylone \\
\hline 12 & $\begin{array}{l}\text { 4-Etylmethcathinone, Fentanyl, 4-Me- } \alpha- \\
\text { ethylaminopentiophenone }\end{array}$ & $\begin{array}{l}\text { 4-Ethylmethcathinone, Fentanyl, 4-Me- } \alpha \text { - } \\
\text { ethylaminopentiophenone }\end{array}$ \\
\hline 13 & FUB-AMB & FUB-AMB \\
\hline 14 & $\begin{array}{c}\text { Cyclopropyl Fentanyl } \\
\text { Insufficient: Heroin }{ }^{\ddagger}, \text { Phenyl Fentany }{ }^{*}\end{array}$ & $\begin{array}{c}\text { Cyclopropyl Fentanyl, Heroin, Phenyl } \\
\text { Fentanyl }\end{array}$ \\
\hline 15 & AB-FUBINACA 2-fluorobenzyl isomer & AB-FUBINACA 2-fluorobenzyl isomer \\
\hline 16 & No Controlled Substances & Not Analyzed \\
\hline 17 & Insufficient: Dibutylone ${ }^{R T}$ & Dibutylone \\
\hline 18 & Acetyl Fentanyl, Fentanyl & Acetyl Fentanyl, Fentanyl \\
\hline 19 & $\begin{array}{c}\text { Fentanyl, Heroin } \\
\text { Insufficient: (Acetyl Fentanyl / FIBF) }\end{array}$ & Acetyl Fentanyl, Fentanyl, FIBF, Heroin \\
\hline 20 & No Controlled Substances & Not Analyzed \\
\hline 21 & No Controlled Substances & Not Analyzed \\
\hline 22 & Fentanyl, XLR11 & Fentanyl, XLR11 \\
\hline 23 & JWH-250 & JWH-250 \\
\hline 24 & JWH-018 & JWH-018 \\
\hline 25 & Insufficient: $\alpha-P V P^{R T}$ & $\alpha-P V P$ \\
\hline 26 & Eutylone & Eutylone \\
\hline 27 & No Controlled Substances & Not Analyzed \\
\hline 28 & 4-Methylethcathinone & 4-Methylethcathinone \\
\hline 29 & 5-Fluoro-AKB48, $\alpha$-PBP & 5-Fluoro-AKB48, $\alpha$-PBP \\
\hline 30 & $\begin{array}{c}\text { JWH-250 } \\
\text { Insufficient: Dibutylone } \\
\text { IT , Fentany }{ }^{*}\end{array}$ & Dibutylone, Fentanyl, JWH-250 \\
\hline 31 & Tramadol & Tramadol \\
\hline 32 & JWH-250 & $\mathrm{JWH}-250$ \\
\hline
\end{tabular}




\begin{tabular}{|c|c|c|}
\hline 33 & $\begin{array}{c}\text { Fentanyl, Heroin } \\
\text { Insufficient: (Acetyl Fentanyl / FIBF) }\end{array}$ & Acetyl Fentanyl, Fentanyl, FIBF, Heroin \\
\hline 34 & Eutylone & Eutylone \\
\hline 35 & $\begin{array}{c}\text { Fentanyl } \\
\text { Insufficient: (Tramado/ / Mannitol) }\end{array}$ & $\begin{array}{c}\text { Fentanyl } \\
\text { Insufficient: (Tramadol | Mannitol) }\end{array}$ \\
\hline 36 & Methyl-AP-237 & Methyl-AP-237 \\
\hline 37 & Heroin & Heroin \\
\hline 38 & JWH-250, a-Methyl Fentanyl & JWH-250, a-Methyl Fentanyl \\
\hline 39 & Insufficient: Fentany ${ }^{\ddagger}$ & Fentanyl \\
\hline 40 & 4-Chloroethcathinone, Cyclopropyl Fentanyl & 4-Chloroethcathinone, Cyclopropyl Fentanyl \\
\hline 41 & No Controlled Substances & Not Analyzed \\
\hline 42 & $\begin{array}{c}\text { Fentanyl, Heroin } \\
\text { Insufficient: (Acetyl Fentanyl / FIBF), } \\
\text { Cocaine }{ }^{\ddagger}\end{array}$ & $\begin{array}{l}\text { Acetyl Fentanyl, Fentanyl, FIBF, Heroin } \\
\text { Insufficient: Cocaine (Not in Targeted } \\
\text { Methods), Noscapine } \neq\end{array}$ \\
\hline 43 & Methylone & Methylone \\
\hline 44 & N-methyl Cyclopropyl norfentanyl & N-methyl Cyclopropyl norfentanyl \\
\hline 45 & No Controlled Substances & Not Analyzed \\
\hline 46 & 4-Methylethcathinone & 4-Methylethcathinone \\
\hline 47 & JWH-018, 3,4-MDPV & JWH-018, 3,4-MDPV \\
\hline 48 & N-Ethylpentylone & $\mathrm{N}$-Ethylpentylone \\
\hline 49 & FUB-AMB & FUB-AMB \\
\hline 50 & Insufficient: $\alpha-P V P^{R T}$ & $\alpha-P V P$ \\
\hline
\end{tabular}

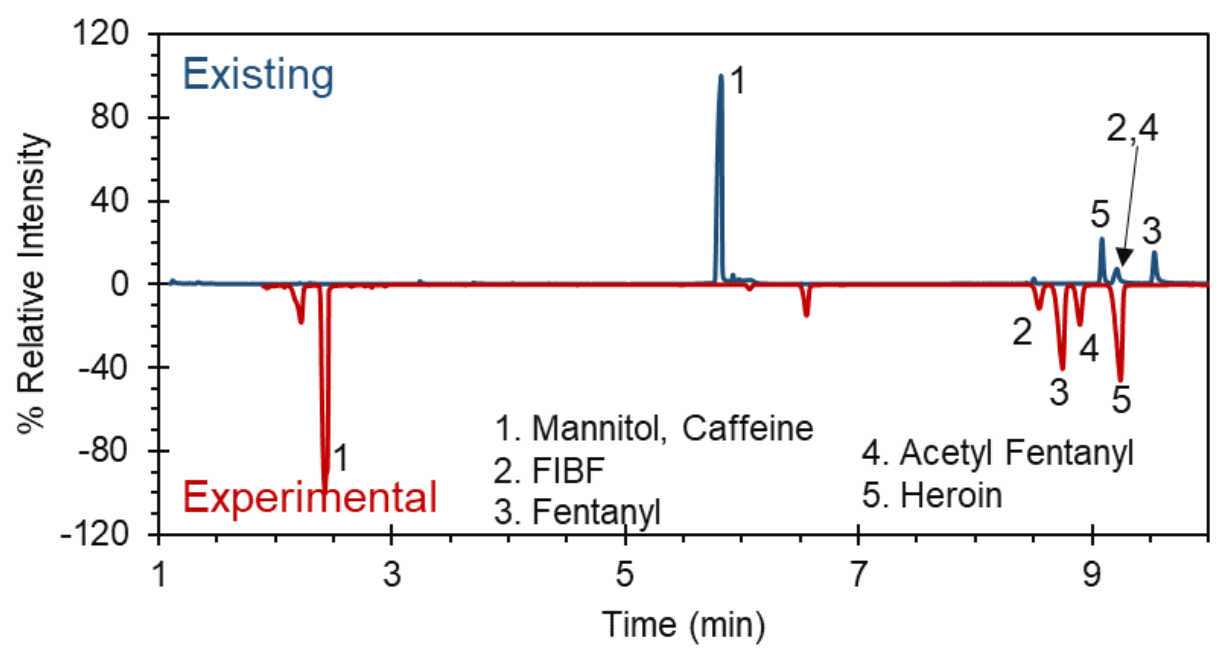

Figure 3. Representative GC-MS chromatograms of Sample 19 analyzed using a general purpose method from the existing workflow (top) and the opioid targeted GC-MS method from the experimental workflow (bottom). Only the first ten minutes of the chromatograms are shown as there were no additional peaks past this point. The elution order was different for the two runs because the methods use different stationary phases.

The biggest difference between the two confirmatory approaches occurred when comparing the time for analysis, summarized in Table 4. As expected, sample preparation for each of the instrumental techniques was almost identical, with GC-FID, general GC-MS, and targeted GC-MS all requiring approximately 10 min to prepare a batch of samples. However, because the existing workflow requires both GC-FID and GCMS, the net time for sample preparation per batch is roughly twice as long. Instrument time was drastically different for the workflows, with the existing workflow requiring a total of $7728.8 \mathrm{~min}$ (128.8 hours) while the 
experimental workflow required only $2853.5 \mathrm{~min}$ (47.6 hours) - inclusive of all samples, reference materials, and positive controls. Using the experimental workflow resulted in a $63 \%$ reduction in time. A major driver for this difference is the large number of reference materials that are required for GC-FID analysis using the existing workflow due to lack of retention time locking, retention indices, or relative retention times. As shown in Table 4, the existing workflow required an average of 25.5 runs per batch, 19.0 of which, on average, came from GC-FID. GC-FID accounted for $68 \%$ of the instrument runtime for the existing workflow.

If GC-FID were removed from the existing workflow, the time comparison between the two approaches becomes more similar. Comparing general purpose GC-MS runs to targeted GC-MS runs resulted in similar instrument runtimes per batch (116 min vs. $143 \mathrm{~min}$, or 1.9 hours vs. 2.4 hours) and a similar number of runs (6.5 average vs. 7.4 average). These values are closer than were expected since samples containing multiple controlled substances needed to be analyzed on multiple targeted methods and because the opioid targeted method was significantly longer than the most commonly used general GC-MS method (35 min compared to $12.67 \mathrm{~min}$ ). Part of what balanced the runtimes was that samples where no controlled substances were identified by DART-MS were not run on targeted GC-MS methods in the experimental workflow. It should be emphasized that using DART-MS as a stopping point for negative samples is something that would need to be thoroughly investigated prior to implementation in a real-world setting and may have too many limitations to be practical.

In terms of data analysis, the general purpose GC-MS analysis and targeted method GC-MS analysis required a similar amount of analyst time, though the targeted method analysis was slightly faster. This is likely due to the use of a locked retention time lookup table where chemists entered the retention time of a peak in a sample and the possible compound(s) that fell within $2 \%$ of that time were shown. Adding in the need to manually compare retention times to standards using GC-FID, the data interpretation component for the existing workflow was found to be almost twice as long as the experimental workflow.

In terms of the amount of sample consumed and the risks to chemists, both confirmatory workflows were nearly identical. The existing workflow does require slightly more material since separate samples are created for GC-FID and GC-MS, but this difference is likely negligible for almost all cases. One potential challenge with the targeted method approach is that it requires different stationary phases (DB-200 and DB-5) which means laboratories would need at least two instruments to leverage such an approach. Alternatively, new methods would need to be developed.

Table 4. Metrics for the GC-FID and GC-MS analyses for both workflows. A further breakdown of these results is shown in Supplemental Table 6 and Supplemental Table 7.

\begin{tabular}{|l|c|c|c|c|}
\hline & \multicolumn{3}{|c|}{ Existing Workflow } & $\begin{array}{c}\text { Experimental } \\
\text { Workflow }\end{array}$ \\
\hline & GC-FID & General GC-MS & $\begin{array}{c}\text { Combined } \\
\text { Total }\end{array}$ & Targeted GC-MS \\
\hline
\end{tabular}




\begin{tabular}{|c|c|c|c|c|}
\hline $\begin{array}{c}\text { Average Sample } \\
\text { Preparation per } \\
\text { Batch (min) }\end{array}$ & $9.0( \pm 2.0)$ & $13.6( \pm 4.0)$ & $22.6( \pm 6.0)$ & $8.8( \pm 1.3)$ \\
\hline $\begin{array}{c}\text { Average Data } \\
\text { Interpretation per } \\
\text { Batch (min) }\end{array}$ & $8.2( \pm 5.4)$ & $22.7( \pm 10.4)$ & $30.9( \pm 15.8)$ & $16.5( \pm 1.5)$ \\
\hline $\begin{array}{c}\text { Average Instrument } \\
\text { Time per Batch } \\
\text { (min) }\end{array}$ & $264.3( \pm 108.9)$ & $116.3( \pm 43.2)$ & $380.6( \pm 152.1)$ & $142.7( \pm 50.0)$ \\
\hline $\begin{array}{c}\text { Cumulative Average } \\
\text { Time per Batch } \\
\text { (min) }\end{array}$ & $281.5( \pm 116.3)$ & $152.6( \pm 57.6)$ & $434.1( \pm 173.9)$ & $168( \pm 52.8)$ \\
\hline $\begin{array}{c}\text { \# Runs per Batch } \\
\text { (Samples + } \\
\text { Standards) }\end{array}$ & 19.0 & 6.5 & 25.5 & 7.4 \\
\hline $\begin{array}{c}\text { Total Instrument } \\
\text { Time (min) }\end{array}$ & 5286.3 & 2442.5 & 7728.8 & 2853.5 \\
\hline
\end{tabular}

\section{Conclusions}

The results of this study demonstrate qualitative and quantitative gains that could be achieved by altering a seized drug workflow. Given the two workflows used here, it was found that screening of samples using color tests and DART-MS required approximately the same amount of time; however, the accuracy and specificity of the data obtained by DART-MS, on average, was superior. The use of DART-MS also eliminated false positives, which were observed with the color tests, and eliminated the need for toxic chemicals and acids. Though DART-MS was studied in combination with targeted GC-MS methods, the improved data quality and results it offers could benefit the existing confirmation workflow as well. While implementation of DART-MS has obvious advantages, the upfront and recurring costs as well as the time required to implement the technique should be considered.

In terms of the confirmation processes studied, major improvements in analysis time were observed alongside some notable gains in analytical capabilities. Temporal benefits were largely driven by the use of a single confirmation tool (targeted GC-MS) in the experimental workflow instead of a dual-technique confirmation. The use of locked retention times provided further instrument time reductions due to the reduced analysis, and consumption, of reference materials. Ongoing work includes investigating the potential benefits of other approaches, such as relative retention times and retention indices, that could reduce the frequency of which reference materials are run. Interestingly, even with the need to analyze a sample on multiple targeted methods, instrument time of the experimental workflow was not substantially greater than the GC-MS analysis of the existing workflow.

An obvious downside to the use of targeted methods is the need to have a panel of compounds, which for this study, was limited to only compounds within the particular drug classes. Adding more commonly coobserved compounds to the method is simple though it does require some time. The targeted methods also highlighted how class-specific methods designed for enhancing separation can address limitations 
presented by general purpose methods. This was observed for multiple compounds (acetyl fentanyl, FIBF, dibutylone, and $\alpha-P V P)$ in the sample set. The use of different chromatographic thresholds for confirmation can also lead to differences in the number of compounds that can be identified.

While implementation of targeted methods may be appealing, they do require the use of an informationrich screening tool. Success of the targeted methods was largely due to the fact that DART-MS provided comprehensive and specific results to enable accurate identification of nearly all controlled substances in the samples. This approach would not have been successful had color tests been used as the screening tool. Another possible use for targeted GC-MS would be to supplement existing general purpose confirmation methods in cases where sufficient separation of compounds is not observed (such as acetyl fentanyl and FIBF). The use of targeted methods requires minimal additional cost and effort beyond the purchase of consumables and method validation; however, depending on the class of compounds of interest, systems with different stationary phases may be required, which could be problematic for laboratories with only one or a few instruments. Another interesting possibility, which was not examined here, is the use of dual-injection methods that would allow for analysis of a sample by GC-FID and GC-MS simultaneously, on two separate stationary phases. Combining two different retention times and mass spectral data may provide additional instances of compound discrimination over any of the abovementioned approaches.

This study highlights some of the strengths and limitations of two specific analytical workflows. Though there are limitations in the experimental workflow, it does highlight some reasons why laboratories may want to consider changes to their protocols. An ideal workflow would certainly look different across laboratories and would be dependent on factors such as: caseload, personnel, types of cases frequently examined, jurisdictional requirements, and access to instrumentation. While it may not be practical to measure all gains and drawbacks prior to implementing changes to analytical protocols, the ability to test these changes, on a small scale, may prove consequential and may limit instances where new techniques are procured but never implemented into casework. Additional studies investigating different analytical workflows are still ongoing and are the focus of current research.

\section{Disclaimers}

Certain commercial products are identified in order to adequately specify the procedure; this does not imply endorsement or recommendation by NIST, nor does it imply that such products are necessarily the best available for the purpose.

Certain commercial products are identified in order to adequately specify the procedure; this does not imply endorsement or recommendation by Maryland State Police, nor does it imply that such products are necessarily the best available for the purpose.

A portion of this work was supported by Award No. 2018-DU-BX-0165, awarded by the National Institute of Justice, Office of Justice Programs, U.S. Department of Justice. The opinions, findings, and conclusions or recommendations expressed in this publication/program/exhibition are those of the author(s) and do not necessarily reflect those of the Department of Justice. 


\section{References}

[1] U.S. Drug Enforcement Administration, Diversion Control Division, National Forensic Laboratory Information System: NFLIS-Drug 2019 Annual Report, U.S. Drug Enforcement Administration, Springfield, VA, 2020.

[2] U.S. Drug Enforcement Administration, Diversion Control Division, National Forensic Laboratory Information System: NFLIS-Drug 2018 Annual Report, U.S. Drug Enforcement Administration, Springfield, VA, 2019.

[3] U.S. Drug Enforcement Administration, Diversion Control Division, NFLIS-Drug 2019 Survey of Crime Laboratory Drug Chemistry Sections Report, U.S. Drug Enforcement Administration, Springfield, VA, 2019.

[4] N.S. Jones, J.H. Comparin, Interpol review of controlled substances 2016-2019, Forensic Science International: Synergy. 2 (2020) 608-669. https://doi.org/10.1016/j.fsisyn.2020.01.019.

[5] E. Sisco, A. Burns, A.S. Moorthy, A Framework for the Development of Targeted Gas

Chromatography Mass Spectrometry (GC-MS) Methods: Synthetic Cannabinoids, Journal of Forensic Sciences. 00 (2021) 000-000. https://doi.org/10.1111/1556-4029.14775.

[6] E. Sisco, T.P. Forbes, Forensic applications of DART-MS: A review of recent literature, Forensic Chemistry. 22 (2021) 100294. https://doi.org/10.1016/j.forc.2020.100294.

[7] R.R. Steiner, R.L. Larson, Validation of the Direct Analysis in Real Time Source for Use in Forensic Drug Screening, Journal of Forensic Sciences. 54 (2009) 617-622. https://doi.org/10.1111/j.15564029.2009.01006.x.

[8] R. Dong, S. Li, D. Lin, H. Chen, L. Yang, Progress of the applications of surface-enhanced Raman spectroscopy in illicit drug detection, Sci. Sin.-Chim. 51 (2020) 294-309. https://doi.org/10.1360/SSC2020-0196.

[9] M.R. Lindberg, S.E. Schmedes, F.C. Hewitt, J.L. Haas, K.L. Ternus, D.R. Kadavy, B. Budowle, A Comparison and Integration of MiSeq and MinION Platforms for Sequencing Single Source and Mixed Mitochondrial Genomes, PLOS ONE. 11 (2016) e0167600. https://doi.org/10.1371/journal.pone.0167600.

[10] S. van der Heijden, S.J. de Oliveira, M.-L. Kampmann, C. Børsting, N. Morling, Comparison of manual and automated AmpliSeq ${ }^{\mathrm{TM}}$ workflows in the typing of a Somali population with the Precision ID Identity Panel, Forensic Science International: Genetics. 31 (2017) 118-125. https://doi.org/10.1016/j.fsigen.2017.09.009.

[11] F. Smith, Handbook of Forensic Drug Analysis, Elsevier, 2004.

[12] E. Sisco, A. Burns, E. Schneider, I. Ikpeama, Evaluation of Internal Standard Inclusion for Qualitative Analysis of Seized Drugs using DART-MS, Unpublished Work. (n.d.).

[13] E. Sisco, A. Burns, A.S. Moorthy, Development and Evaluation of a Synthetic Cathinone Targeted Gas Chromatography Mass Spectrometry (GC-MS) Method, Journal of Forensic Sciences. Just Accepted. (n.d.). https://doi.org/10.1111/1556-4029.14789. 


\title{
Supplemental Information for: \\ Comparing Two Analytical Workflows for Seized Drug Analysis of Synthetic Cannabinoids, Cathinones, and Opioids
}

\author{
Edward Sisco ${ }^{a}$, Amber Burns ${ }^{b}$, Elizabeth Schneider ${ }^{b}$, Charles R. Miller, IVc, Laurel Bobka ${ }^{c}$ \\ aNational Institute of Standards and Technology, Gaithersburg, MD \\ bMaryland State Police Forensic Sciences Division, Pikesville, MD \\ 'Maryland State Police Forensic Sciences Division, Hagerstown, MD \\ edward.sisco@nist.gov
}

Supplemental Table 1. Method parameters for the two GC-FID methods used in the existing workflow.

\begin{tabular}{|c|c|c|}
\hline Method & $\mathbf{A}$ & B \\
\hline Instrument & Agilent 7890 & Agilent 6890 \\
\hline Column & $\begin{array}{c}\text { DB-5 } \\
15 \mathrm{~m} \times 0.25 \mathrm{~mm} \times 0.25 \mu \mathrm{m}\end{array}$ & $\begin{array}{c}\text { DB-5MS } \\
20 \mathrm{~m} \times 0.18 \mathrm{~mm} \times 0.18 \mu \mathrm{m}\end{array}$ \\
\hline Temperature Program & 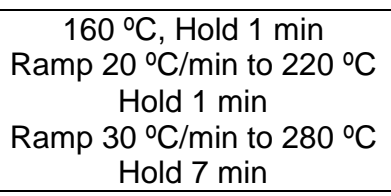 & $\begin{array}{c}150 \stackrel{\circ}{\circ} \mathrm{C}, \text { Hold } 1 \mathrm{~min} \\
\text { Ramp } 30^{\circ} \mathrm{C} / \mathrm{min} \text { to } 290^{\circ} \mathrm{C} \\
\text { Hold } 7 \mathrm{~min}\end{array}$ \\
\hline Flow Rate & $1.44 \mathrm{~mL} / \mathrm{min}$ & $\begin{array}{c}0.8 \mathrm{~mL} / \mathrm{min} \\
10 \mathrm{~mL} / \mathrm{min}^{2} \text { to } 1.8 \mathrm{~mL} / \mathrm{min} \text { at } \\
3 \mathrm{~min} \\
\text { Hold } 1.8 \mathrm{~mL} / \mathrm{min}\end{array}$ \\
\hline Injection Volume & $1 \mu \mathrm{L}$ & $1 \mu \mathrm{L}$ \\
\hline Inlet Temperature & $250^{\circ} \mathrm{C}$ & $250^{\circ} \mathrm{C}$ \\
\hline Split Ratio & $50: 1$ & $20: 1$ \\
\hline Detector Temperature & $280^{\circ} \mathrm{C}$ & $300^{\circ} \mathrm{C}$ \\
\hline Data Collection Rate & $50 \mathrm{~Hz}$ & $50 \mathrm{~Hz}$ \\
\hline Total Run Time & $15 \min$ & $12.67 \mathrm{~min}$ \\
\hline
\end{tabular}


Supplemental Table 2. Reference material sets required to be run for GC-FID verification. Only compounds that required multiple reference materials to be run are listed. The number of reference materials required is listed in parenthesis.

\begin{tabular}{|c|c|}
\hline Compound in Study & Reference Materials Run \\
\hline AB-FUBINACA 2-fluorobenzyl isomer (6) & $\begin{array}{c}\text { AB-FUBINACA } \\
\text { AB-FUBINACA 2-fluorobenzyl isomer } \\
\text { AB-FUBINACA 3-fluorobenzyl isomer } \\
\text { AB-FUBINACA isomer } 1 \\
\text { AB-FUBINACA isomer } 2 \\
\text { AB-FUBINACA isomer } 5 \\
\end{array}$ \\
\hline 4-Chloroethcathinone (6) & $\begin{array}{l}\text { 2-Chloroethcathinone } \\
\text { 3-Chloroethcathinone } \\
\text { 3-Chloro-N,N-Dimethylcathinone } \\
\text { 4-Chlorobuphedrone } \\
\text { 4-Chloroethcathinone } \\
\text { 4-Chloro-N,N-Dimethylcathinone }\end{array}$ \\
\hline Crotonyl Fentanyl or Cyclopropyl Fentanyl (2) & $\begin{array}{c}\text { Crotonyl Fentanyl } \\
\text { Cyclopropyl Fentanyl } \\
\end{array}$ \\
\hline Dibutylone or Eutylone (9) & $\begin{array}{c}\text { Dibutylone } \\
\text { Eutylone } \\
\text { 2,3-Eutylone } \\
\text { 3,4-Methylenedioxy- } \alpha \text {-methylamino-isovalerophenone } \\
\text { 3,4-Methylenedioxy-N-isopropylcathinone } \\
\text { 3,4-Methylenedioxy-N-propylcathinone } \\
\text { N-Methylethylone } \\
\text { Pentylone } \\
\text { 2,3-Pentylone } \\
\end{array}$ \\
\hline 4-Ethylmethcathinone (6) & $\begin{array}{c}\text { 2,3-Dimethylmethcathinone } \\
\text { 2,4-Dimethylmethcathinone } \\
\text { 3,4-Dimethylmethcathinone } \\
\text { 2-Ethylmethcathinone } \\
\text { 3-Ethylmethcathinone } \\
\text { 4-Ethylmethcathinone }\end{array}$ \\
\hline N-Ethylpentylone (7) & 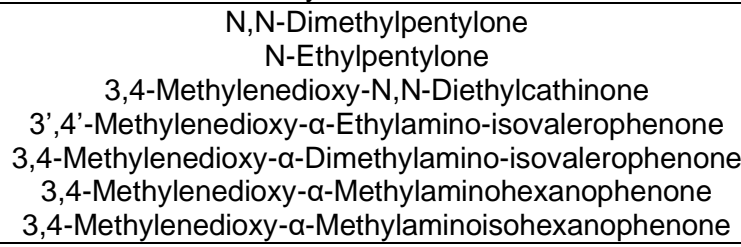 \\
\hline FIBF (3) & $\begin{array}{l}\text { FIBF } \\
\begin{array}{c}\text { m-Fluoroisobutyryl fentanyl } \\
\text { o-Fluoroisobutyryl fentanyl }\end{array} \\
\end{array}$ \\
\hline JWH-250 (2) & $\begin{array}{l}\mathrm{JWH}-250 \\
\text { JWH-302 } \\
\end{array}$ \\
\hline 3,4-MDPV (2) & $\begin{array}{l}\text { 2,3-MDPV } \\
\text { 3,4-MDPV }\end{array}$ \\
\hline Methamphetamine (2) & $\begin{array}{c}\text { Phentermine } \\
\text { Methamphetamine } \\
\end{array}$ \\
\hline 4-Methyl-a-Ethylaminopentiophenone (3) & $\begin{array}{c}\text { 4-Methyl-a-Ethylaminopentiophenone } \\
\text { 4-Methyl-N-Methylhexanophenone } \\
\text { 4-Methyldiethcathinone } \\
\end{array}$ \\
\hline 4-Methylethcathinone (6) & $\begin{array}{l}\text { 2-Methylethcathinone } \\
\text { 3-Methylethcathinone } \\
\text { 4-Methyl-N,N-Dimethylcathinone } \\
\text { 3-Methylbuphedrone } \\
\text { 4-Methylethcathinone } \\
\text { 4-Methylbuphedrone } \\
\end{array}$ \\
\hline Methylone (2) & $\begin{array}{c}\text { 2,3-Methylenedioxymethcathinone } \\
\text { Methylone }\end{array}$ \\
\hline$\alpha-P V P(2)$ & $\begin{array}{c}\alpha-P I P B P \\
\alpha-P V P \\
\end{array}$ \\
\hline
\end{tabular}


Supplemental Table 3. Method parameters for the three general purpose GC-MS methods used in the existing workflow.

\begin{tabular}{|c|c|c|c|}
\hline Method & $\mathbf{A}$ & $\mathbf{B}$ & C \\
\hline Instrument & Agilent 7890/5977B & Agilent 7890/5977B & Agilent 6890/5975B \\
\hline Column & $\begin{array}{c}\text { HP-5ms Ultra Inert } \\
30 \mathrm{~m} \times 0.25 \mathrm{~mm} \times 0.25 \mu \mathrm{m}\end{array}$ & $\begin{array}{c}\text { HP-5ms Ultra Inert } \\
30 \mathrm{~m} \times 0.25 \mathrm{~mm} \times 0.25 \mu \mathrm{m}\end{array}$ & $\begin{array}{c}\text { DB-5MS } \\
20 \mathrm{~m} \times 0.18 \mathrm{~mm} \times 0.18 \mu \mathrm{m}\end{array}$ \\
\hline $\begin{array}{c}\text { Temperature } \\
\text { Program }\end{array}$ & $\begin{array}{c}120^{\circ} \mathrm{C}, \text { Hold } 1 \mathrm{~min} \\
\text { Ramp } 25^{\circ} \mathrm{C} / \mathrm{min} \text { to } 280^{\circ} \mathrm{C} \\
\text { Hold } 20 \mathrm{~min}\end{array}$ & $\begin{array}{c}180^{\circ} \mathrm{C}, \text { Hold } 0 \text { min } \\
\text { Ramp } 30^{\circ} \mathrm{C} / \mathrm{min} \text { to } 280^{\circ} \mathrm{C} \\
\text { Hold } 8 \text { min }\end{array}$ & $\begin{array}{c}150^{\circ} \mathrm{C}, \text { Hold } 1 \text { min } \\
\text { Ramp } 30^{\circ} \mathrm{C} / \min \text { to } 290^{\circ} \mathrm{C} \\
\text { Hold } 7 \text { min }\end{array}$ \\
\hline Flow Rate & $1.6 \mathrm{~mL} / \mathrm{min}$ & $1.8 \mathrm{~mL} / \mathrm{min}$ & $\begin{array}{c}0.8 \mathrm{~mL} / \mathrm{min} \\
10 \mathrm{~mL} / \mathrm{min}^{2} \text { to } 1.8 \mathrm{~mL} / \mathrm{min} \text { at } \\
3 \mathrm{~min} \\
\text { Hold } 1.8 \mathrm{~mL} / \mathrm{min}\end{array}$ \\
\hline Injection Volume & $1 \mu \mathrm{L}$ & $1 \mu \mathrm{L}$ & $1 \mu \mathrm{L}$ \\
\hline Inlet Temperature & $250^{\circ} \mathrm{C}$ & $250^{\circ} \mathrm{C}$ & $250^{\circ} \mathrm{C}$ \\
\hline Split Ratio & $50: 1$ & $50: 1$ & $30: 1$ \\
\hline Transfer Line & $280^{\circ} \mathrm{C}$ & $280^{\circ} \mathrm{C}$ & $280^{\circ} \mathrm{C}$ \\
\hline Quad Temperature & $150^{\circ} \mathrm{C}$ & $150^{\circ} \mathrm{C}$ & $150^{\circ} \mathrm{C}$ \\
\hline Source Temperature & $230^{\circ} \mathrm{C}$ & $230 \div \mathrm{C}$ & $230^{\circ} \mathrm{C}$ \\
\hline Tune Mode & stune & stune & stune \\
\hline Solvent Delay & $1.4 \mathrm{~min}$ & $1.15 \mathrm{~min}$ & $1.2 \mathrm{~min}$ \\
\hline Mass Scan Range & $m / z 40-m / z 550$ & $m / z 40-m / z 550$ & $m / z 40-m / z 550$ \\
\hline Threshold & 150 counts & 150 counts & 300 counts \\
\hline Scan Speed & $\mathrm{N}=2[\approx 4 \mathrm{scan} / \mathrm{s}]$ & $\mathrm{N}=2[\approx 4 \mathrm{scan} / \mathrm{s}]$ & $\mathrm{N}=2[\approx 4 \mathrm{scan} / \mathrm{s}]$ \\
\hline Total Run Time & $27.4 \mathrm{~min}$ & $11.33 \mathrm{~min}$ & $12.67 \mathrm{~min}$ \\
\hline
\end{tabular}

Supplemental Table 4. Method parameters for the three targeted GC-MS methods used for the experimental workflow. All analyses were completed on an Agilent 7890/5977B.

\begin{tabular}{|c|c|c|c|}
\hline Compound Class & Cannabinoids & Cathinones & Opioids \\
\hline Lock Compound & AB-FUBINACA & Butylone & Fentanyl \\
\hline Column & $\begin{array}{c}\text { DB-200 } \\
30 \mathrm{~m} \times 0.25 \mathrm{~mm} \times 0.25 \mu \mathrm{m}\end{array}$ & $\begin{array}{c}\text { DB-5 } \\
30 \mathrm{~m} \times 0.25 \mathrm{~mm} \times 0.25 \mu \mathrm{m}\end{array}$ & $\begin{array}{c}\text { DB-200 } \\
30 \mathrm{~m} \times 0.25 \mathrm{~mm} \times 0.25 \mu \mathrm{m}\end{array}$ \\
\hline $\begin{array}{l}\text { Temperature } \\
\text { Program }\end{array}$ & Isothermal at $290^{\circ} \mathrm{C}$ & $\begin{array}{c}190^{\circ} \mathrm{C} \text { for } 0.5 \min \\
\text { Ramp } 5^{\circ} \mathrm{C} / \mathrm{min} \text { to } 210^{\circ} \mathrm{C} \\
\text { Ramp at } 30^{\circ} \mathrm{C} / \min \text { to } 255^{\circ} \mathrm{C} \\
\text { Hold } 1.5 \mathrm{~min}\end{array}$ & $\begin{array}{c}2300^{\circ} \mathrm{C} \text { for } 0.0 \mathrm{~min} \\
\text { Ramp at } 2^{\circ} \mathrm{C} / \mathrm{min} \text { to } 290{ }^{\circ} \mathrm{C} \\
\text { Hold } 5.0 \text { min }\end{array}$ \\
\hline Flow Rate & $1.2 \mathrm{~mL} / \mathrm{min}$ & $1.9 \mathrm{~mL} / \mathrm{min}$ & $1.2 \mathrm{~mL} / \mathrm{min}$ \\
\hline Injection Volume & $1.0 \mu \mathrm{L}$ & $1.0 \mu \mathrm{L}$ & $1.0 \mu \mathrm{L}$ \\
\hline Inlet Temperature & $300^{\circ} \mathrm{C}$ & $300^{\circ} \mathrm{C}$ & $300^{\circ} \mathrm{C}$ \\
\hline Split Ratio & $30: 1$ & $30: 1$ & $20: 1$ \\
\hline Transfer Line & $300^{\circ} \mathrm{C}$ & $300^{\circ} \mathrm{C}$ & $300^{\circ} \mathrm{C}$ \\
\hline Quad Temperature & $150{ }^{\circ} \mathrm{C}$ & $150^{\circ} \mathrm{C}$ & $150^{\circ} \mathrm{C}$ \\
\hline Source Temperature & $280^{\circ} \mathrm{C}$ & $280^{\circ} \mathrm{C}$ & $280^{\circ} \mathrm{C}$ \\
\hline Tune Mode & stune & stune & stune \\
\hline Solvent Delay & $1.4 \mathrm{~min}$ & $1.15 \mathrm{~min}$ & $1.3 \mathrm{~min}$ \\
\hline Mass Scan Range & $m / z 40-m / z 550$ & $m / z 40-m / z 550$ & $m / z 40-m / z 550$ \\
\hline Threshold & 150 counts & 150 counts & 150 counts \\
\hline Scan Speed & $\mathrm{N}=2[\approx 4 \mathrm{scan} / \mathrm{s}]$ & $\mathrm{N}=2[\approx 4 \mathrm{scan} / \mathrm{s}]$ & $\mathrm{N}=2[\approx 4 \mathrm{scan} / \mathrm{s}]$ \\
\hline Total Run Time & $12.0 \mathrm{~min}$ & $7.5 \mathrm{~min}$ & $35.0 \mathrm{~min}$ \\
\hline
\end{tabular}


Supplemental Table 5. Scores and results obtained for the color test (existing workflow) and DART-MS (experimental workflow) portions of the study. For each sample, scores are listed in the first row and the results listed in the second. For the color tests, results are shown in the following order: Mayers, cobalt thiocyanate, and Marquis from left to right represented by the color observed. A cell with an " $X$ " indicates no reaction. DART-MS results for only the controlled substances are listed. DART-MS results were identical for both chemists except for Sample 42 where FIBF and noscapine were only identified by one chemist, as denoted with "(1)". In the Contents column, compound names with a double dagger ( $\left.{ }^{\ddagger}\right)$ are compounds in a sample that, when previously analyzed, were found to be at concentrations too low for confirmation.

\begin{tabular}{|c|c|c|c|c|c|c|c|c|c|}
\hline \multirow{2}{*}{ Sample } & \multirow{2}{*}{ Contents } & \multicolumn{6}{|c|}{ Color Test } & \multicolumn{2}{|c|}{ DART-MS } \\
\hline & & \multicolumn{3}{|c|}{ Score 1} & \multicolumn{3}{|c|}{ Score 2} & Score 1 & Score 2 \\
\hline \multirow{2}{*}{1} & \multirow{2}{*}{$\begin{array}{l}\text { No Controlled Substance } \\
\text { Pill Binder }\end{array}$} & \multicolumn{3}{|c|}{4} & \multicolumn{3}{|c|}{4} & 4 & 4 \\
\hline & & $\mathrm{X}$ & $\mathrm{X}$ & $\mathrm{x}$ & $\mathrm{x}$ & $\mathrm{X}$ & $\mathrm{x}$ & \multicolumn{2}{|c|}{ No Controlled Substances } \\
\hline \multirow{2}{*}{2} & \multirow{2}{*}{ Methamphetamine } & \multicolumn{3}{|c|}{4} & \multicolumn{3}{|c|}{4} & 4 & 4 \\
\hline & & \multicolumn{3}{|c|}{$\mathrm{x}$} & & $\mathrm{x}$ & & \multicolumn{2}{|c|}{ Methamphetamine } \\
\hline \multirow{2}{*}{3} & \multirow{2}{*}{$\begin{array}{c}\text { Heroin, MDMA } \\
\text { Mannitol, Quinine }\end{array}$} & \multirow{2}{*}{\multicolumn{3}{|c|}{3}} & \multicolumn{3}{|c|}{3} & 2 & 2 \\
\hline & & & & & & \multicolumn{2}{|c|}{ MDMA } \\
\hline \multirow{2}{*}{4} & Fentanyl, Tramadol $^{\ddagger}$ & & 1 & & & 1 & & 4 & 4 \\
\hline & & & & & & & & Fent & nadol \\
\hline & MPHP & & -1 & & & 1 & & 4 & 4 \\
\hline 5 & Dextromethorphan & & & & & & & & \\
\hline 6 & MDMA & & 4 & & & 4 & & 4 & 4 \\
\hline 6 & MIDIVIA & & $x$ & & & $x$ & & & \\
\hline 7 & No Controlled Substance & & 4 & & & 4 & & 4 & 4 \\
\hline$r$ & Mannitol & $\mathrm{X}$ & $\mathrm{X}$ & $\mathrm{X}$ & $\mathrm{X}$ & $\mathrm{X}$ & $\mathrm{X}$ & No Con & ostances \\
\hline 8 & Heroin & & 4 & & & 4 & & 4 & 4 \\
\hline 0 & Papaverine & & & & & & & & \\
\hline 0 & Methy Norfontany & & 0 & & & 0 & & 4 & 4 \\
\hline y & 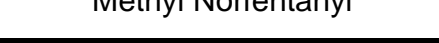 & & & $\mathrm{X}$ & & & $\mathrm{x}$ & Met & tanyl \\
\hline 10 & 4-Ethylmethcathinone & & 0 & & & 0 & & 3 & 3 \\
\hline 10 & & & & $\mathrm{X}$ & & & & Cath & 192 \\
\hline 11 & Dibutylone & & 1 & & & 1 & & 3 & 3 \\
\hline 11 & Caffeine & & & & & & & Cath & 236 \\
\hline & 4-Ethylmethcathinone, & & -1 & & & 1 & & 3 & 3 \\
\hline 12 & $\begin{array}{l}\text { Fentanyl, 4-Me- } \alpha- \\
\text { ethylaminopentiophenone }\end{array}$ & & $\mathrm{X}$ & & & & & $\begin{array}{r}\text { Fentanyl, } \\
\text { Catt }\end{array}$ & $\begin{array}{l}\mathrm{m} / \mathrm{z} 220 \\
z 192\end{array}$ \\
\hline 12 & FIP $A M P$ & & 0 & & & 0 & & 4 & 4 \\
\hline 13 & FUB-AIVIB & $\mathrm{X}$ & $x$ & & $\mathrm{x}$ & $\mathrm{X}$ & & & \\
\hline & Cyclopropyl Fentanyl, Heroin, & & 1 & & & 1 & & 3 & 3 \\
\hline 14 & $\begin{array}{c}\text { Phenyl Fentanyl } \\
\text { Caffeine, Mannitol } \\
\end{array}$ & & & & & & & $\begin{array}{r}\text { Cycloprop } \\
\mathrm{Ph}\end{array}$ & $\begin{array}{l}\text { lor isomer, } \\
\text { anyl }\end{array}$ \\
\hline 15 & AB-FUBINACA 2-fluorobenzyl & & 0 & & & 0 & & 3 & 3 \\
\hline 15 & isomer & $\mathrm{X}$ & $x$ & $\mathrm{X}$ & $\mathrm{X}$ & $\mathrm{X}$ & $\mathrm{X}$ & AB-FUI & \\
\hline 16 & No Controlled Substance & & 4 & & & 4 & & 4 & 4 \\
\hline 16 & Inorganic Compound & $\mathrm{X}$ & $\bar{x}$ & $\mathrm{X}$ & $\mathrm{X}$ & $x$ & $\mathrm{X}$ & No Con & stances \\
\hline 17 & Dibutvlono & & 1 & & & 1 & & 3 & 3 \\
\hline 17 & Didoutyione & & & & & & & Cath & 236 \\
\hline 18 & Acetyl Fentanyl, Fentanyl & & 1 & & & 0 & & 3 & 3 \\
\hline 10 & Mannitol, Quinine & & & & & & $\mathrm{X}$ & Acetyl Fenta & ner, Fentanyl \\
\hline & Heroin, Acetyl Fentany $\left.\right|^{\ddagger}$, & & 1 & & & 1 & & 3 & 3 \\
\hline 19 & $\begin{array}{c}\text { Caffeine, Lidocaine, Mannitol, } \\
\text { Quinine }\end{array}$ & & & & & & & $\begin{array}{l}\text { Acetyl Fenta } \\
\text { FIBF }\end{array}$ & $\begin{array}{l}\text { ler, Fentanyl, } \\
\text { Heroin }\end{array}$ \\
\hline 20 & No Controlled Substance & & -1 & & & -1 & & 4 & 4 \\
\hline
\end{tabular}




\begin{tabular}{|c|c|c|c|c|c|c|c|c|c|}
\hline & Guaifenesin, Quinine & & & & & & & \multicolumn{2}{|c|}{ No Controlled Substances } \\
\hline \multirow[b]{2}{*}{21} & No Controlled Substance & \multicolumn{3}{|c|}{4} & \multicolumn{3}{|c|}{4} & 4 & 4 \\
\hline & $\begin{array}{c}\text { Acetaminophen, Citric Acid, } \\
\text { Xylitol }\end{array}$ & $\mathrm{x}$ & $\mathrm{x}$ & $\mathrm{x}$ & $\mathrm{x}$ & $\mathrm{x}$ & $\mathrm{x}$ & \multicolumn{2}{|c|}{ No Controlled Substances } \\
\hline \multirow{2}{*}{22} & \multirow{2}{*}{ Fentanyl, XLR11 } & \multicolumn{3}{|c|}{0} & \multicolumn{3}{|c|}{0} & 3 & 3 \\
\hline & & & $\mathrm{x}$ & & & $\mathrm{x}$ & & \multicolumn{2}{|c|}{ Fentanyl, XLR11 } \\
\hline \multirow{2}{*}{23} & \multirow{2}{*}{ JWH-250 } & \multicolumn{3}{|c|}{0} & \multicolumn{3}{|c|}{0} & 3 & 3 \\
\hline & & \multirow{2}{*}{\multicolumn{3}{|c|}{$\frac{x}{1}$}} & $\mathrm{x}$ & & & \multicolumn{2}{|c|}{ JWH-250 or isomer } \\
\hline \multirow{2}{*}{24} & \multirow{2}{*}{ JWH-018 } & -1 & & & \multicolumn{3}{|c|}{-1} & 4 & 4 \\
\hline & & $x$ & $\mathrm{X}$ & & \multicolumn{3}{|c|}{$\mathrm{x}$} & & \\
\hline 25 & $\alpha-P Y P$ & & 0 & & & 0 & & 4 & 4 \\
\hline 25 & $\alpha-P V P$ & & & $x$ & & & $\mathrm{x}$ & & \\
\hline 26 & Eutylone & & 1 & & & 1 & & 3 & 3 \\
\hline 20 & Caffeine & & & & & & & & \\
\hline & No Controlled Substance & & 4 & & & 4 & & 4 & 4 \\
\hline 27 & Caffeine & $\mathrm{x}$ & $\mathrm{x}$ & $\mathrm{x}$ & $\mathrm{X}$ & $\mathrm{x}$ & $\mathrm{X}$ & No $O$ & ances \\
\hline & & & $\overline{0}$ & & & -1 & & 3 & 3 \\
\hline 28 & 4-Mlethylethcathınone & & $\mathrm{X}$ & $\mathrm{X}$ & & & & & \\
\hline & 5-Fluoro-AKB48, $\alpha$-PBP & & 0 & & & 0 & & 3 & 3 \\
\hline 29 & Mannitol & & $\mathrm{x}$ & $\mathrm{X}$ & & & $\mathrm{X}$ & $5-\mathrm{F}-\mathrm{A}$ & somer \\
\hline & & & 1 & & & 1 & & 3 & 3 \\
\hline 30 & Dibutylone, Fentanyl, JWH-250 & & & & & & & Cathinone & anyl, JWH- \\
\hline & Tramadol & & 0 & & & 1 & & 4 & 4 \\
\hline 31 & Dextromethorphan & & & & & & & & \\
\hline 32 & JWH-250 & & 0 & & & 0 & & 3 & 3 \\
\hline 32 & JWH-250 & $\mathrm{x}$ & $\mathrm{X}$ & & $\mathrm{x}$ & $\mathrm{X}$ & & & \\
\hline & Fentanyl, Heroin, Acetyl & & 0 & & & 2 & & 3 & 3 \\
\hline 33 & $\begin{array}{l}\text { Fentanyl }^{\ddagger}, \mathrm{FIBF}^{\ddagger} \\
\text { Caffeine, Quinine }\end{array}$ & $\mathrm{x}$ & & & & & & $\begin{array}{r}\text { Acetyl Fe } \\
\text { FIB }\end{array}$ & $\begin{array}{l}\text { Fentanyl, } \\
\text { roin }\end{array}$ \\
\hline 34 & Eutylone & & 3 & & & 3 & & 3 & 3 \\
\hline 34 & & $\mathrm{x}$ & & & $\mathrm{x}$ & $\mathrm{X}$ & & & \\
\hline & Fentanyl, Tramadol $^{\ddagger}$ & & 2 & & & 2 & & 3 & 3 \\
\hline 35 & $\begin{array}{l}\text { Caffeine, Levamisole, Mannitol, } \\
\text { N-Phenylpropanamide, Procaine }\end{array}$ & & & & & & & & \\
\hline 36 & Mothbu P 227 & & 3 & & & 3 & & 3 & 3 \\
\hline 30 & 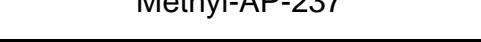 & & & & & & & Meth & -238 \\
\hline 37 & Hernin & & 3 & & & 3 & & 4 & 4 \\
\hline $3 r$ & петоाп & & & & & & & & \\
\hline & & & 0 & & & 2 & & 3 & 3 \\
\hline 38 & JWH-250, $\alpha$-Methyl Fentanyl & $\mathrm{x}$ & $\mathrm{x}$ & & & & & JWH-250 & yl Fentanyl \\
\hline $39+>-1$ & Fentanyl & & -1 & & & 0 & & 4 & 4 \\
\hline 39 & Caffeine, Quinine, Xylazine & & & & $\mathrm{x}$ & $\mathrm{X}$ & $\mathrm{x}$ & & \\
\hline & & & 2 & & & 1 & & 3 & 3 \\
\hline 40 & $\begin{array}{l}\text { 4-Chioroethcatninone, } \\
\text { Cyclopropyl Fentanyl }\end{array}$ & & & & & & & $\begin{array}{r}\text { Cathino } \\
\mathrm{F} \\
\end{array}$ & $\begin{array}{l}\text { lopropyl } \\
\text { er }\end{array}$ \\
\hline 41 & No Controlled Substance & & 4 & & & 0 & & 4 & 4 \\
\hline 41 & Mannitol & $\mathrm{x}$ & $\mathrm{X}$ & $\mathrm{X}$ & & $\mathrm{x}$ & $\mathrm{x}$ & No $C$ & ances \\
\hline & Heroin, Acetyl Fentanyl ${ }^{\ddagger}$ & & 2 & & & 2 & & 2 & 2 \\
\hline 42 & $\begin{array}{c}\text { Cocaine }^{\ddagger}, \text { Fentany }^{\ddagger}, \text { FIBF }^{\ddagger}, \\
\text { Noscapine } \\
\text { Caffeine, Quinine }\end{array}$ & & & & & & & $\begin{array}{r}\text { Acetyl Fe } \\
\text { FIBF } \\
\end{array}$ & $\begin{array}{l}\text { Fentanyl, } \\
\text { eroin, }\end{array}$ \\
\hline 43 & Methvlone & & 1 & & & 1 & & 3 & 3 \\
\hline 40 & & & $\mathrm{x}$ & & & $\mathrm{X}$ & & & \\
\hline
\end{tabular}




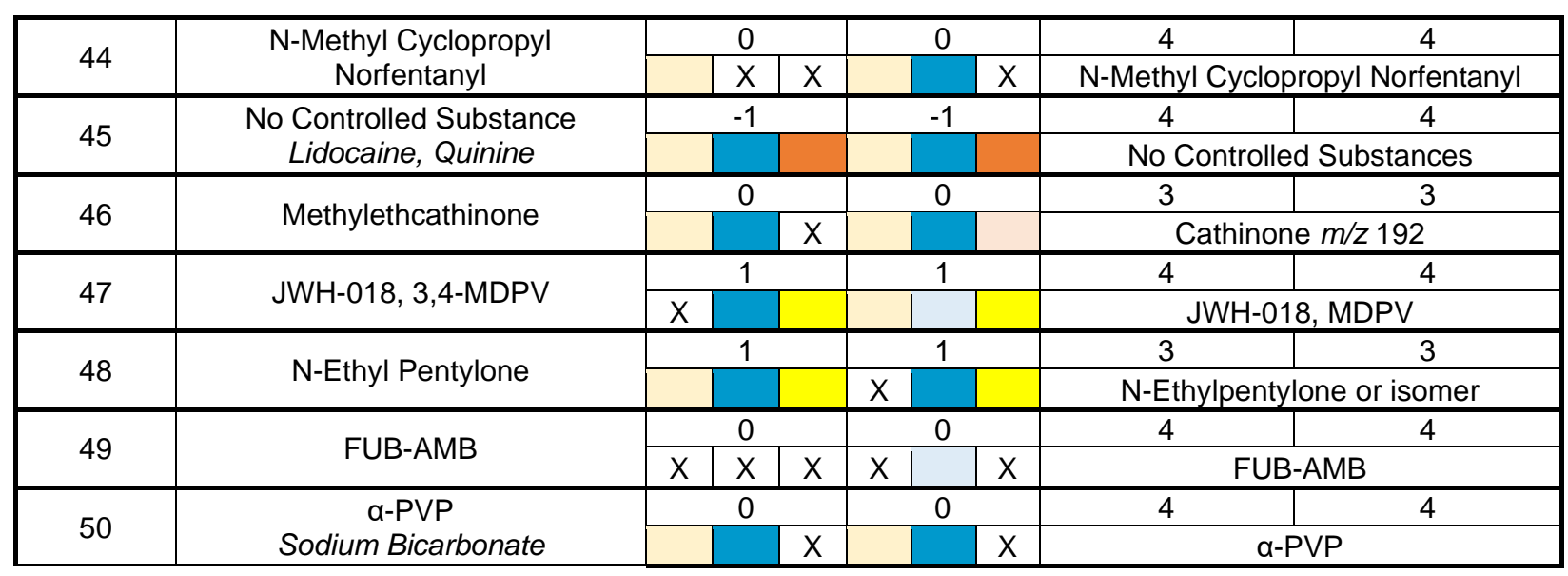


Supplemental Table 6. Summary results for the GC-FID and GC-MS confirmatory analyses using the existing workflow broken down by batch. Method letters correspond to those listed in Supplemental Table 1 (GC-FID) and 3 (GC-MS). Reference materials required are based on Supplemental Table 2. Compounds that were detected but could not be confirmed are listed as insufficient, and the reason for the insufficient designation is provided. A double dagger $\left(^{\ddagger}\right)$ indicates that the compound was not at a high enough abundance in the GC-MS chromatogram for confirmation, a superscript RT (RT) indicates that there were multiple similar compound with overlapping retention time windows which precluded confirmation, and compounds in parentheses indicate instances where co-elution precluded confirmation.

\begin{tabular}{|c|c|c|c|}
\hline \multicolumn{4}{|r|}{ Chemist 1 - Batch 1} \\
\hline Sample \# & $\begin{array}{l}\text { GC-FID } \\
\text { Method }\end{array}$ & $\begin{array}{l}\text { GC-MS } \\
\text { Method }\end{array}$ & Controlled Substances Identified \\
\hline 1 & A & A & No Controlled Substances \\
\hline 2 & A & A & Methamphetamine \\
\hline 3 & A & A & Heroin $n^{\ddagger}$, MDMA \\
\hline 4 & A & A & Fentany $^{\ddagger}$, Tramado ${ }^{\ddagger}$ \\
\hline 5 & A & A & MPHP \\
\hline $\begin{array}{l}\text { Cumulative } \\
\text { Standards / } \\
+ \text { Controls }\end{array}$ & 7 & 1 & $\begin{array}{c}\text { FID: Methamphetamine, Phentermine, MDMA, Heroin, Fentanyl, } \\
\text { Tramadol, MPHP } \\
\text { MS: Cocaine }\end{array}$ \\
\hline \multirow{2}{*}{\multicolumn{4}{|c|}{ Chemist 1 - Batch 2}} \\
\hline & & & \\
\hline Sample \# & $\begin{array}{l}\text { GC-FID } \\
\text { Method }\end{array}$ & $\begin{array}{l}\text { GC-MS } \\
\text { Method }\end{array}$ & Controlled Substances Identified \\
\hline 21 & $\mathrm{~A}$ & $\mathrm{~A}$ & No Controlled Substances \\
\hline 22 & A & A & Fentanyl, XLR11 \\
\hline 23 & A & A & JWH-250 \\
\hline 24 & A & A & JWH-018 \\
\hline 25 & A & A & Insufficient: $\alpha-P V P^{R T}$ \\
\hline $\begin{array}{l}\text { Cumulative } \\
\text { Standards / } \\
\text { + Controls }\end{array}$ & 7 & 1 & $\begin{array}{c}\text { FID: XLR11, Fentanyl, JWH-250, JWH-302, JWH-018, } \alpha-P V P, \alpha- \\
\text { PIPBP } \\
\text { MS: Cocaine }\end{array}$ \\
\hline Runtime (min) & 180 & 164.4 & \\
\hline \multicolumn{4}{|r|}{ Chemist 1 - Batch 3} \\
\hline Sample \# & $\begin{array}{l}\text { GC-FID } \\
\text { Method }\end{array}$ & $\begin{array}{l}\text { GC-MS } \\
\text { Method }\end{array}$ & Controlled Substances Identified \\
\hline 26 & A & A & Eutylone \\
\hline 27 & A & A & No Controlled Substabces \\
\hline 28 & A & A & 4-Methylethcathinone \\
\hline 29 & A & A & a-PBP, 5-F-AKB48 \\
\hline 30 & A & A & $\begin{array}{c}\text { Fentanyl, JWH-250 } \\
\text { Insufficient: Dibutylone } \\
\text { RT }\end{array}$ \\
\hline $\begin{array}{l}\text { Cumulative } \\
\text { Standards / } \\
+ \text { Controls }\end{array}$ & 20 & 1 & $\begin{array}{c}\text { FID: Set of } 6 \text { 4-Methylethcathinone compounds, Set of } 9 \\
\text { Dibutylone/Eutylone compounds, a-PBP, 5-F-AKB48, Fentanyl, JWH- } \\
\text { 250, JWH-302 } \\
\text { MS: Cocaine }\end{array}$ \\
\hline Runtime (min) & 375 & 164.4 & \\
\hline \multicolumn{4}{|r|}{ Chemist 1 - Batch 4} \\
\hline Sample \# & $\begin{array}{l}\text { GC-FID } \\
\text { Method }\end{array}$ & $\begin{array}{l}\text { GC-MS } \\
\text { Method }\end{array}$ & Controlled Substances Identified \\
\hline 36 & A & A & Methyl-AP-237 \\
\hline 37 & A & A & Heroin \\
\hline 38 & A & A & JWH-250, a-Methyl Fentanyl \\
\hline 39 & A & A & Insufficient: Fentany/ \\
\hline 40 & A & A & 4-Chloroethcathinone, Cyclopropyl Fentanyl \\
\hline $\begin{array}{l}\text { Cumulative } \\
\text { Standards / } \\
+ \text { Controls }\end{array}$ & 14 & 1 & $\begin{array}{c}\text { FID: AP-238, Heroin, a-Methyl Fentanyl, JWH-250, JWH-302, } \\
\text { Fentanyl, Set of } 6 \text { 4-Chloroethcathinone compounds, Cyclopropyl } \\
\text { Fentanyl, Crotonyl Fentanyl } \\
\text { MS: Cocaine }\end{array}$ \\
\hline
\end{tabular}




\begin{tabular}{|c|c|c|c|}
\hline Runtime (min) & 285 & 164.4 & \\
\hline \multicolumn{4}{|r|}{ Chemist 1 - Batch 5} \\
\hline Sample \# & $\begin{array}{l}\text { GC-FID } \\
\text { Method }\end{array}$ & $\begin{array}{l}\text { GC-MS } \\
\text { Method }\end{array}$ & Controlled Substances Identified \\
\hline 41 & A & A & No Controlled Substances \\
\hline 42 & A & A & Fentanyl, Heroin \\
\hline 43 & A & A & Methylone \\
\hline 44 & A & A & N-Methyl Cyclopropyl Fentanyl \\
\hline 45 & A & A & No Controlled Substances \\
\hline $\begin{array}{l}\text { Cumulative } \\
\text { Standards / } \\
+ \text { Controls }\end{array}$ & 5 & 1 & $\begin{array}{l}\text { FID: Heroin, Fentanyl, Methylone, 2,3-MDMC, N-Methyl Cyclopropyl } \\
\text { norfentanyl } \\
\text { MS: Cocaine }\end{array}$ \\
\hline Runtime (min) & 150 & 164.4 & \\
\hline \multicolumn{4}{|r|}{ Chemist 2 - Batch 1} \\
\hline Sample \# & $\begin{array}{l}\text { GC-FID } \\
\text { Method }\end{array}$ & $\begin{array}{l}\text { GC-MS } \\
\text { Method }\end{array}$ & Controlled Substances Identified \\
\hline 6 & A & $\mathrm{B}$ & MDMA \\
\hline 7 & A & A & No Controlled Substances \\
\hline 8 & A & $\mathrm{B}$ & Heroin \\
\hline 9 & A & A & N-Methyl Norfentanyl \\
\hline 10 & A & A & 4-Ethylmethcathinone \\
\hline $\begin{array}{l}\text { Cumulative } \\
\text { Standards / } \\
+ \text { Controls }\end{array}$ & 9 & $\begin{array}{l}A-1 \\
B-1\end{array}$ & $\begin{array}{l}\text { FID: MDMA, Heroin, Methyl Norfentanyl, Set of } 64- \\
\text { Ethylmethcathinone compounds } \\
\text { MS (A): Cocaine } \\
\text { MS (B): Cocaine }\end{array}$ \\
\hline Runtime (min) & 210 & 143.6 & \\
\hline \multicolumn{4}{|r|}{ Chemist 2 - Batch 2} \\
\hline Case \# & $\begin{array}{l}\text { GC-FID } \\
\text { Method }\end{array}$ & $\begin{array}{l}\text { GC-MS } \\
\text { Method }\end{array}$ & Compound ID \\
\hline 11 & $\mathrm{~A}$ & $\mathrm{~A}$ & Insufficient: Dibutylone ${ }^{R T}$ \\
\hline 12 & A & $\mathrm{B}$ & 4-Ethylmethcathinone, Fentanyl, 4-Me- $\alpha$-Ethylaminopentiophenone \\
\hline 13 & A & $\mathrm{B}$ & FUB-AMB \\
\hline 14 & A & A & $\begin{array}{l}\text { Cyclopropyl Fentanyl, Heroin } \\
\text { Insufficient: Phenyl Fentany }{ }^{\ddagger}\end{array}$ \\
\hline 15 & A & $\bar{A}$ & AB-FUBINACA 2-fluorobenzyl isomer \\
\hline $\begin{array}{l}\text { Cumulative } \\
\text { Standards / } \\
+ \text { Controls }\end{array}$ & 30 & $\begin{array}{l}A-1 \\
B-2\end{array}$ & $\begin{array}{c}\text { FID: Set of } 6 \text { AB-FUBINACA compounds, Set of } 9 \text { Dibutylone } \\
\text { compounds, Set of } 6 \text { 4-Ethylmethcathinone compounds, Fentanyl, Set } \\
\text { of } 3 \text { 4-Me- } \alpha \text {-Ethylaminopentionphenone compounds, FUB-AMB, } \\
\text { Heroin, Cyclopropyl Fentanyl, Crotonyl Fentanyl, Phenyl Fentanyl } \\
\text { MS(A): Cocaine } \\
\text { MS(B): Cocaine, Fentanyl (missing molecular ion) }\end{array}$ \\
\hline Runtime (min) & 525 & 154.9 & \\
\hline \multicolumn{4}{|r|}{ Chemist 2 - Batch 3} \\
\hline Sample \# & $\begin{array}{l}\text { GC-FID } \\
\text { Method }\end{array}$ & $\begin{array}{l}\text { GC-MS } \\
\text { Method }\end{array}$ & Controlled Substances Identified \\
\hline 16 & A & A & No Controlled Substances \\
\hline 17 & A & A & Insufficient: Dibutylone ${ }^{R T}$ \\
\hline 18 & A & A & Acetyl Fentanyl, Fentanyl \\
\hline 19 & A & A & $\begin{array}{c}\text { Fentanyl, Heroin } \\
\text { Insufficient: (Acetyl Fentanyl / FIBF) }\end{array}$ \\
\hline 20 & A & A & No Controlled Substances \\
\hline $\begin{array}{l}\text { Cumulative } \\
\text { Standards / } \\
+ \text { Controls }\end{array}$ & 17 & 1 & $\begin{array}{l}\text { FID (A): Acetyl fentanyl, Fentanyl, Set of } 3 \text { FIBF compounds, Heroin } \\
\text { FID (B): Set of } 9 \text { Dibutylone compounds, Acetyl fentanyl, Fentanyl } \\
\text { MS: Cocaine }\end{array}$ \\
\hline Runtime (min) & 330 & 164.4 & \\
\hline
\end{tabular}




\begin{tabular}{|c|c|c|c|}
\hline \multicolumn{4}{|r|}{ Chemist 2 - Batch 4} \\
\hline Sample \# & $\begin{array}{l}\text { GC-FID } \\
\text { Method }\end{array}$ & $\begin{array}{l}\text { GC-MS } \\
\text { Method }\end{array}$ & Controlled Substances Identified \\
\hline 31 & $\mathrm{~A}$ & $\mathrm{~A}$ & Tramadol \\
\hline 32 & A & A & JWH-250 \\
\hline 33 & A & A & $\begin{array}{c}\text { Fentanyl, Heroin } \\
\text { Insufficient: (Acetyl Fentanyl / FIBF) }\end{array}$ \\
\hline 34 & A & A & Eutylone \\
\hline 35 & A & B & Fentanyl \\
\hline $\begin{array}{l}\text { Cumulative } \\
\text { Standards / } \\
\text { + Controls }\end{array}$ & 19 & $\begin{array}{l}A-1 \\
B-1\end{array}$ & $\begin{array}{l}\text { FID (A): Acetyl Fentanyl, Fentanyl, Set of } 3 \text { FIBF compounds, Heroin } \\
\text { FID (B): Tramadol, JWH-250, JWH-302, Set of } 9 \text { Eutylone } \\
\text { compounds, Fentanyl } \\
\text { MS (A): Cocaine } \\
\text { MS (B): Cocaine }\end{array}$ \\
\hline Runtime (min) & 360 & 159.7 & \\
\hline \multicolumn{4}{|r|}{ Chemist 2 - Batch 5} \\
\hline Sample \# & $\begin{array}{l}\text { GC-FID } \\
\text { Method }\end{array}$ & $\begin{array}{l}\text { GC-MS } \\
\text { Method }\end{array}$ & Controlled Substances Identified \\
\hline 46 & A & $\mathrm{A}$ & 4-Methylethcathinone \\
\hline 47 & A & A & JWH-018, 3,4-MDPV \\
\hline 48 & A & A & $\mathrm{N}$-Ethylpentylone \\
\hline 49 & A & B & FUB-AMB \\
\hline 50 & $\mathrm{~A}$ & A & Insufficient: $\alpha-P V P^{R T}$ \\
\hline $\begin{array}{l}\text { Cumulative } \\
\text { Standards / } \\
\text { + Controls }\end{array}$ & 19 & $\begin{array}{l}A-2 \\
B-1\end{array}$ & $\begin{array}{l}\text { FID: Set of } 6 \text { 4-Methylethcathinone compounds, 2,3-MDPV, 3,4- } \\
\text { MDPV, JWH-018, Set of } 7 \text { N-Ethylpentylone compounds, FUB-AMB, } \\
\text { a-PVP, a-PIPBP } \\
\text { MS (A): Cocaine, MDPV (missing molecular ion) } \\
\text { MS(B): Cocaine }\end{array}$ \\
\hline Runtime (min) & 360 & 187.1 & \\
\hline \multicolumn{4}{|r|}{ Chemist 3 - Batch 1} \\
\hline Sample \# & $\begin{array}{l}\text { GC-FID } \\
\text { Method }\end{array}$ & $\begin{array}{l}\text { GC-MS } \\
\text { Method }\end{array}$ & Controlled Substances Identified \\
\hline 1 & $\mathrm{~B}$ & $\mathrm{C}$ & No Controlled Substances \\
\hline 3 & $\mathrm{~B}$ & C & MDMA \\
\hline 5 & $\mathrm{~B}$ & C & MPHP \\
\hline 7 & $\mathrm{~B}$ & $\mathrm{C}$ & No Controlled Substances \\
\hline 9 & $\mathrm{~B}$ & $\mathrm{C}$ & N-Methyl Norfentanyl \\
\hline $\begin{array}{l}\text { Cumulative } \\
\text { Standards / } \\
+ \text { Controls }\end{array}$ & 3 & 1 & $\begin{array}{l}\text { FID: MDMA, MPHP, N-Methyl Norfentanyl } \\
\text { MS: Cocaine }\end{array}$ \\
\hline Runtime (min) & 101.4 & 76 & \\
\hline \multicolumn{4}{|r|}{ Chemist 3 - Batch 2} \\
\hline Sample \# & $\begin{array}{l}\text { GC-FID } \\
\text { Method }\end{array}$ & $\begin{array}{l}\text { GC-MS } \\
\text { Method }\end{array}$ & Controlled Substances Identified \\
\hline 12 & $\mathrm{~B}$ & $\mathrm{C}$ & 4-Ethylmethcathinone, Fentanyl, 4-Me-a-Ethylaminopentiophenone \\
\hline 14 & B & C & $\begin{array}{c}\text { Cyclopropyl Fentanyl } \\
\text { Insufficient: Heroin } ¥ \text {, Phenyl Fentany/ }\end{array}$ \\
\hline 16 & $\mathrm{~B}$ & $\mathrm{C}$ & No Controlled Substances \\
\hline 18 & $\mathrm{~B}$ & $\mathrm{C}$ & Insufficient: Acetyl Fentany ${ }^{\ddagger}$, Fentany ${ }^{\ddagger}$ \\
\hline 20 & $\mathrm{~B}$ & $\mathrm{C}$ & No Controlled Substances \\
\hline $\begin{array}{l}\text { Cumulative } \\
\text { Standards / } \\
\text { + Controls }\end{array}$ & 15 & 3 & $\begin{array}{c}\text { FID: Set of } 6 \text { 4-Ethylmethcathinone compounds, Set of } 3 \text { 4-Me-a- } \\
\text { Ethylaminopentiophenone compounds, Fentanyl, Crotonyl Fentanyl, } \\
\text { Cyclopropyl Fentanyl, Heroin, Acetyl Fentanyl } \\
\text { MS: Cocaine, 4-Ethylmethcathinone (missing molecular ion), Fentanyl } \\
\text { (missing molecular ion) }\end{array}$ \\
\hline Runtime (min) & 153.4 & 101.4 & \\
\hline
\end{tabular}




\begin{tabular}{|c|c|c|c|}
\hline \multicolumn{4}{|r|}{ Chemist 3- Batch 3} \\
\hline Sample \# & $\begin{array}{l}\text { GC-FID } \\
\text { Method }\end{array}$ & $\begin{array}{l}\text { GC-MS } \\
\text { Method }\end{array}$ & Controlled Substances Identified \\
\hline 21 & $\mathrm{~B}$ & $\mathrm{C}$ & No Controlled Substances \\
\hline 23 & $\mathrm{~B}$ & $\mathrm{C}$ & JWH-250 \\
\hline 25 & $\mathrm{~B}$ & $\mathrm{C}$ & Insufficient: $\alpha-P V P^{R T}$ \\
\hline 27 & B & C & No Controlled Substances \\
\hline 29 & $\mathrm{~B}$ & $\mathrm{C}$ & 5-F-AKB48, $\alpha$-PBP \\
\hline $\begin{array}{l}\text { Cumulative } \\
\text { Standards / } \\
+ \text { Controls }\end{array}$ & 6 & 1 & $\begin{array}{l}\text { FID: JWH-250, JWH-302, a-PVP, a-PIPBP, a-PBP, 5-F-AKB48 } \\
\text { MS: Cocaine }\end{array}$ \\
\hline Runtime (min) & 139.4 & 76 & \\
\hline \multicolumn{4}{|r|}{ Chemist 3 - Batch 4} \\
\hline Sample \# & $\begin{array}{l}\text { GC-FID } \\
\text { Method }\end{array}$ & $\begin{array}{l}\text { GC-MS } \\
\text { Method }\end{array}$ & Controlled Substances Identified \\
\hline 32 & $\mathrm{~B}$ & $\mathrm{C}$ & JWH-250 \\
\hline 34 & $\mathrm{~B}$ & $\mathrm{C}$ & Eutylone \\
\hline 36 & $\mathrm{~B}$ & $\mathrm{C}$ & Methyl-AP-237 \\
\hline 38 & B & C & JWH-250, $\alpha$-Methyl Fentanyl \\
\hline 40 & $\mathrm{~B}$ & $\mathrm{C}$ & 4-Chloroethcathinone, Cyclopropyl Fentanyl \\
\hline $\begin{array}{l}\text { Cumulative } \\
\text { Standards / } \\
+ \text { Controls }\end{array}$ & 21 & 2 & $\begin{array}{l}\text { FID: JWH-250, JWH-302, Set of } 9 \text { Eutylone compounds, AP-238, } \alpha- \\
\text { Methyl Fentanyl, Cyclopropyl Fentanyl, Crotonyl Fentanyl, Set of } 6 \text { - } \\
\text { Chloroethcathinone compounds } \\
\text { MS: Cocaine, Eutylone (missing molecular ion) }\end{array}$ \\
\hline Runtime (min) & 329.4 & 88.7 & \\
\hline \multicolumn{4}{|r|}{ Chemist 3 - Batch 5} \\
\hline Sample \# & $\begin{array}{l}\text { GC-FID } \\
\text { Method }\end{array}$ & $\begin{array}{l}\text { GC-MS } \\
\text { Method }\end{array}$ & Controlled Substances Identified \\
\hline 41 & $\mathrm{~B}$ & $\mathrm{C}$ & No Controlled Substances \\
\hline 43 & $\mathrm{~B}$ & C & Methylone \\
\hline 45 & B & C & No Controlled Substances \\
\hline 47 & $\mathrm{~B}$ & $\mathrm{C}$ & $\mathrm{JWH}-018,3,4-\mathrm{MDPV}$ \\
\hline 49 & $\mathrm{~B}$ & C & FUB-AMB \\
\hline $\begin{array}{l}\text { Cumulative } \\
\text { Standards / } \\
+ \text { Controls }\end{array}$ & 6 & 2 & $\begin{array}{c}\text { FID: Methylone, MDMC, 3,4-MDPV, 2,3-MDPV, JWH-018, FUB-AMB } \\
\text { MS: Cocaine, 3,4-MDPV (missing molecular ion) }\end{array}$ \\
\hline Runtime (min) & 139.4 & 88.7 & \\
\hline \multicolumn{4}{|r|}{ Chemist 4 - Batch 1} \\
\hline Sample \# & $\begin{array}{l}\text { GC-FID } \\
\text { Method }\end{array}$ & $\begin{array}{l}\text { GC-MS } \\
\text { Method }\end{array}$ & Controlled Substances Identified \\
\hline 2 & $\mathrm{~B}$ & $\mathrm{C}$ & Methamphetamine \\
\hline 4 & $\mathrm{~B}$ & $\mathrm{C}$ & Fentanyl, Tramadol \\
\hline 6 & $\mathrm{~B}$ & C & MDMA \\
\hline 8 & $\mathrm{~B}$ & $\mathrm{C}$ & Heroin \\
\hline 10 & $\mathrm{~B}$ & $\mathrm{C}$ & 4-Ethylmethcathinone \\
\hline $\begin{array}{l}\text { Cumulative } \\
\text { Standards / } \\
+ \text { Controls }\end{array}$ & 12 & 1 & $\begin{array}{c}\text { FID: Methamphetamine, Phentermine, Tramadol, Fentanyl, MDMA, } \\
\text { Heroin, Set of } 6 \text { 4-Ethylmethcathinone compounds } \\
\text { MS: Cocaine }\end{array}$ \\
\hline Runtime (min) & 215.4 & 76 & \\
\hline
\end{tabular}




\begin{tabular}{|c|c|c|c|}
\hline \multicolumn{4}{|r|}{ Chemist 4 - Batch 2} \\
\hline Sample \# & $\begin{array}{l}\text { GC-FID } \\
\text { Method }\end{array}$ & $\begin{array}{l}\text { GC-MS } \\
\text { Method }\end{array}$ & Controlled Substances Identified \\
\hline 11 & $\mathrm{~B}$ & $\mathrm{C}$ & Insufficient: Dibutylone ${ }^{R T}$ \\
\hline 13 & $\mathrm{~B}$ & $\mathrm{C}$ & FUB-AMB \\
\hline 15 & B & $\mathrm{C}$ & Insufficient: AB-FUBINACA 2-fluorobenzyl isomer \\
\hline 17 & $\mathrm{~B}$ & $\mathrm{C}$ & Insufficient: Dibutylone ${ }^{R T}$ \\
\hline 19 & B & C & $\begin{array}{c}\text { Fentanyl, Heroin } \\
\text { Insufficient: (Acetyl Fentanyl / FIBF) } \\
\end{array}$ \\
\hline $\begin{array}{l}\text { Cumulative } \\
\text { Standards / } \\
+ \text { Controls }\end{array}$ & 22 & 1 & $\begin{array}{c}\text { FID: Set of } 9 \text { Eutylone/Dibutylone compounds, FUB-AMB, Set of } 6 \\
\text { AB-FUBINACA compounds, Acetyl Fentanyl, Fentanyl, Set of } 3 \text { FIB } \\
\text { compounds, Heroin } \\
\text { MS: Cocaine }\end{array}$ \\
\hline Runtime (min) & 342.1 & 76 & \\
\hline \multicolumn{4}{|r|}{ Chemist 4 - Batch 3} \\
\hline Sample \# & $\begin{array}{l}\text { GC-FID } \\
\text { Method }\end{array}$ & $\begin{array}{l}\text { GC-MS } \\
\text { Method }\end{array}$ & Controlled Substances Identified \\
\hline 22 & $\mathrm{~B}$ & $\mathrm{C}$ & Fentanyl, XLR11 \\
\hline 24 & $\mathrm{~B}$ & C & JWH-018 \\
\hline 26 & $\mathrm{~B}$ & $\mathrm{C}$ & Eutylone \\
\hline 28 & $\mathrm{~B}$ & C & 4-Methylethcathinone \\
\hline 30 & B & C & $\begin{array}{c}\text { Fentanyl, JWH-250 } \\
\text { Insufficient: Dibutylone }\end{array}$ \\
\hline $\begin{array}{l}\text { Cumulative } \\
\text { Standards / } \\
+ \text { Controls }\end{array}$ & 20 & 1 & $\begin{array}{l}\text { FID: XLR11, Fentanyl, JWH-018, Set of } 9 \text { Eutylone/Dibutylone } \\
\text { compounds, Set of } 6 \text { 4-Methylethcathinone compounds, JWH-250, } \\
\text { JWH-302 } \\
\text { MS: Cocaine }\end{array}$ \\
\hline Runtime (min) & 316.8 & 76 & \\
\hline \multicolumn{4}{|r|}{ Chemist 4 - Batch 4} \\
\hline Sample \# & $\begin{array}{l}\text { GC-FID } \\
\text { Method }\end{array}$ & $\begin{array}{l}\text { GC-MS } \\
\text { Method }\end{array}$ & Controlled Substances Identified \\
\hline 31 & $\mathrm{~B}$ & $\mathrm{C}$ & Tramadol \\
\hline 33 & B & C & $\begin{array}{c}\text { Fentanyl, Heroin } \\
\text { Insufficient: (Acetyl Fentanyl / FlBF⿱ })\end{array}$ \\
\hline 35 & B & C & $\begin{array}{c}\text { Fentanyl } \\
\text { Insufficient: (Tramadol / Mannitol) }\end{array}$ \\
\hline 37 & $\mathrm{~B}$ & $\mathrm{C}$ & Heroin \\
\hline 39 & $\mathrm{~B}$ & $\mathrm{C}$ & Insufficient: Fentany $\left.\right|^{\ddagger}$ \\
\hline $\begin{array}{l}\text { Cumulative } \\
\text { Standards / } \\
+ \text { Controls }\end{array}$ & 7 & 1 & $\begin{array}{l}\text { FID: Tramadol, Acetyl Fentanyl, Fentanyl, Set of } 3 \text { FIBF compounds, } \\
\text { Heroin } \\
\text { MS: Cocaine }\end{array}$ \\
\hline Runtime (min) & 152 & 76 & \\
\hline \multicolumn{4}{|r|}{ Chemist 4 - Batch 5} \\
\hline Sample \# & $\begin{array}{l}\text { GC-FID } \\
\text { Method }\end{array}$ & $\begin{array}{l}\text { GC-MS } \\
\text { Method }\end{array}$ & Controlled Substances Identified \\
\hline 42 & B & C & $\begin{array}{c}\text { Fentanyl } \\
\text { Insufficient: (Acetyl Fentanyl / FIBF) }\end{array}$ \\
\hline 44 & $\mathrm{~B}$ & $\mathrm{C}$ & N-Methyl Cyclopropyl Norfentanyl \\
\hline 46 & $\mathrm{~B}$ & $\mathrm{C}$ & 4-Methylethcathinone \\
\hline 48 & $\mathrm{~B}$ & $\mathrm{C}$ & N-Ethylpentylone \\
\hline 50 & $\mathrm{~B}$ & $\mathrm{C}$ & Insufficient: $\alpha-P V P^{R T}$ \\
\hline $\begin{array}{l}\text { Cumulative } \\
\text { Standards / } \\
+ \text { Controls } \\
\end{array}$ & 22 & 1 & $\begin{array}{l}\text { FID: Acetyl Fentanyl, Fentanyl Set of } 3 \text { FIBF compounds, Heroin, N- } \\
\text { Methyl Cyclopropyl norfentanyl, Set of } 6 \text { 4-Methylethcathinone } \\
\text { compounds, Set of } 7 \text { N-Ethylpentylone compounds, a-PVP, a-PIPBP } \\
\text { MS: Cocaine }\end{array}$ \\
\hline Runtime (min) & 342.1 & 76 & \\
\hline
\end{tabular}


Supplemental Table 7. Batch results for the targeted GC-MS confirmation analyses. An " $X$ " indicates that the sample was run on the targeted method listed ("Cath." indicates the synthetic cathinone method and "Cann." indicates the synthetic cannabinoid method). The total instrument time and number of runs for each batch are also provided along with the compounds that were confirmed in each sample. Compounds that were detected but could not be confirmed are listed as insufficient, and the reason for the insufficient designation is provided. A double dagger $\left(^{\ddagger}\right)$ indicates that the compound was not at a high enough abundance in the GC-MS chromatogram for confirmation and compounds in parentheses indicate instances where co-elution precluded confirmation.

\begin{tabular}{|c|c|c|c|c|}
\hline \multicolumn{5}{|r|}{ Chemist 1 - Batch 1} \\
\hline Sample \# & Opioid & Cath. & Cann. & Controlled Substances Identified \\
\hline 6 & & $\mathrm{X}$ & & MDMA \\
\hline 7 & & & & Not Analyzed - No Controlled Substances ID'ed in DART-MS \\
\hline 8 & $\mathrm{X}$ & & & Heroin \\
\hline 9 & $\bar{X}$ & & & N-Methyl Norfentanyl \\
\hline 10 & & $\mathrm{X}$ & & 4-Ethylmethcathinone \\
\hline + Control & $\mathrm{X}$ & $\mathrm{X}$ & & \begin{tabular}{l|l} 
Runtime: $146.7 \mathrm{~min}$ & \# Runs: 6
\end{tabular} \\
\hline \multicolumn{5}{|r|}{ Chemist 1 - Batch 2} \\
\hline Sample \# & Opioid & Cath. & Cann. & Controlled Substances Identified \\
\hline 11 & & $\mathrm{X}$ & & Dibutylone \\
\hline 12 & $\mathrm{X}$ & $\mathrm{X}$ & & 4-Ethylmethcathinone, Fentanyl, 4-Me- $\alpha$-ethylaminopentiophenone \\
\hline 13 & & & $\mathrm{X}$ & FUB-AMB \\
\hline 14 & $\mathrm{X}$ & & & Cyclopropyl Fentanyl, Heroin, Phenyl Fentanyl \\
\hline 15 & & & $\bar{X}$ & AB-FUBINACA 2-fluorobenzyl isomer \\
\hline+ Control & $\mathrm{X}$ & $\mathrm{X}$ & $\mathrm{X}$ & \begin{tabular}{c|c} 
Runtime: $163.5 \mathrm{~min}$ & \# Runs: 9 \\
\end{tabular} \\
\hline \multicolumn{5}{|r|}{ Chemist 1 - Batch 3} \\
\hline Sample \# & Opioid & Cath. & Cann. & Controlled Substances Identified \\
\hline 16 & & & & Not Analyzed - No Controlled Substances ID'ed in DART-MS \\
\hline 17 & & $\mathrm{X}$ & & Dibutylone \\
\hline 18 & $\bar{X}$ & & & Acetyl Fentanyl, Fentanyl \\
\hline 19 & $\mathrm{X}$ & & & Acetyl Fentanyl, Fentanyl, FIBF, Heroin \\
\hline 20 & & & & Not Analyzed - No Controlled Substances ID'ed in DART-MS \\
\hline+ Control & $\mathrm{X}$ & $\mathrm{X}$ & & \begin{tabular}{c|c} 
Runtime: $120 \mathrm{~min}$ & \# Runs: 5 \\
\end{tabular} \\
\hline \multicolumn{5}{|r|}{ Chemist 1 - Batch 4} \\
\hline Sample \# & Opioid & Cath. & Cann. & $\begin{array}{c}\text { Controlled Substances Identified } \\
\end{array}$ \\
\hline 31 & $\mathrm{X}$ & & & Tramadol \\
\hline 32 & & & $\mathrm{X}$ & JWH-250 \\
\hline 33 & $\mathrm{X}$ & & & Acetyl Fentanyl, Fentanyl, FIBF, Heroin \\
\hline 34 & & $\mathrm{X}$ & & Eutylone \\
\hline 35 & $\mathrm{X}$ & & & $\begin{array}{c}\text { Fentanyl } \\
\text { Insufficient: (Tramadol / Mannitol) }\end{array}$ \\
\hline+ Control & $\mathrm{X}$ & $\mathrm{X}$ & $\mathbf{X}$ & \begin{tabular}{l|l} 
Runtime: 214 min & \# Runs: 9
\end{tabular} \\
\hline & & & & Chemist 1 - Batch 5 \\
\hline Sample \# & Opioid & Cath. & Cann. & Controlled Substances Identified \\
\hline 46 & & $\mathrm{X}$ & & 4-Methylethcathinone \\
\hline 47 & & $\mathrm{X}$ & $\mathrm{X}$ & JWH-018, 3,4-MDPV \\
\hline 48 & & $\mathrm{X}$ & & $\mathrm{N}$-Ethylpentylone \\
\hline 49 & & & $x$ & \multirow{2}{*}{$\begin{array}{c}\text { FUB-AMB } \\
\alpha-P V P\end{array}$} \\
\hline 50 & & $x$ & & \\
\hline + Control & & $X$ & $\mathrm{X}$ & Runtime: $73.5 \mathrm{~min}$ \\
\hline
\end{tabular}




\begin{tabular}{|c|c|c|c|c|}
\hline \multicolumn{5}{|r|}{ Chemist 2 - Batch 1} \\
\hline Sample \# & Opioid & Cath. & Cann. & Controlled Substances Identified \\
\hline 1 & & & & Not Analyzed - No Controlled Substances ID'ed in DART-MS \\
\hline 2 & & & & Not Analyzed - No Targeted Method for Methamphetamine \\
\hline 3 & $\mathrm{X}$ & $\mathrm{X}$ & & Heroin, MDMA \\
\hline 4 & $\mathrm{X}$ & $\mathrm{X}$ & & $\begin{array}{c}\text { Fentanyl } \\
\text { Insufficient: (Tramadol / Mannitol) }\end{array}$ \\
\hline 5 & & & & MPHP \\
\hline+ Control & $\mathrm{X}$ & $\mathrm{X}$ & & Runtime: $127.5 \mathrm{~min}$ \\
\hline \multicolumn{5}{|r|}{ Chemist 2 - Batch 2} \\
\hline Sample \# & Opioid & Cath. & Cann. & Controlled Substances Identified \\
\hline 21 & & & & Not Analyzed - No Controlled Substances ID'ed in DART-MS \\
\hline 22 & $\bar{x}$ & & $\mathrm{X}$ & Fentanyl, XLR11 \\
\hline 23 & & & $\mathrm{X}$ & JWH-250 \\
\hline 24 & & & $\mathrm{X}$ & JWH-018 \\
\hline 25 & & $\mathrm{X}$ & & $\alpha$-PVP \\
\hline + Control & $\mathrm{X}$ & $\mathrm{X}$ & $\mathrm{X}$ & Runtime: $133 \mathrm{~min}$ \\
\hline \multicolumn{5}{|r|}{ Chemist 2 - Batch 3} \\
\hline Sample \# & Opioid & Cath. & Cann. & Controlled Substances Identified \\
\hline 26 & & $\mathrm{X}$ & & Eutylone \\
\hline 27 & & & & Not Analyzed - No Controlled Substances ID'ed in DART-MS \\
\hline 28 & & $\mathrm{X}$ & & 4-Methylethcathinone \\
\hline 29 & & $\mathrm{X}$ & $\mathrm{X}$ & 5-F-AKB48, a-PBP \\
\hline 30 & $\mathrm{X}$ & $\mathrm{X}$ & $\mathrm{X}$ & Dibutylone, Fentanyl, JWH-250 \\
\hline+ Control & $\mathrm{X}$ & $\mathrm{X}$ & $\mathrm{X}$ & \begin{tabular}{l|l} 
Runtime: $143.5 \mathrm{~min}$ & \# Runs: 10 \\
\end{tabular} \\
\hline \multirow{2}{*}{\multicolumn{5}{|c|}{$\begin{array}{l}\text { Chemist } 2 \text { - Batch } 4 \\
\text { Controlled Substances Identified }\end{array}$}} \\
\hline & & & & \\
\hline 36 & $\mathrm{x}$ & & & Methyl-AP-237 \\
\hline 37 & $\mathrm{X}$ & & & Heroin \\
\hline 38 & $\mathrm{X}$ & & $\mathrm{X}$ & JWH-250, a-Methyl Fentanyl \\
\hline 39 & $\mathrm{X}$ & & & Fentanyl \\
\hline 40 & $\bar{X}$ & $\mathrm{X}$ & & 4-Chloroethcathinone, Cyclopropyl Fentanyl \\
\hline+ Control & $\mathrm{X}$ & $\mathrm{X}$ & $\mathrm{X}$ & \begin{tabular}{l|l} 
Runtime: 249 min & \# Runs: 10 \\
\end{tabular} \\
\hline \multicolumn{5}{|r|}{ Chemist 2 - Batch 5} \\
\hline Sample \# & Opioid & Cath. & Cann. & Controlled Substances Identified \\
\hline 41 & & & & Not Analyzed - No Controlled Substances ID'ed in DART-MS \\
\hline 42 & $\mathrm{X}$ & & & $\begin{array}{c}\text { Acetyl Fentanyl, Fentanyl, FIBF, Heroin } \\
\text { Insufficient: Cocaine (Not in Targeted Methods), Noscapine }\end{array}$ \\
\hline 43 & & $\mathrm{X}$ & & Methylone \\
\hline 44 & $\mathrm{X}$ & & & N-Methyl Cyclopropyl Norfentanyl \\
\hline 45 & & & & Not Analyzed - No Controlled Substances ID'ed in DART-MS \\
\hline + Control & $\mathrm{X}$ & $\mathrm{X}$ & & \begin{tabular}{l|l} 
Runtime: $120 \mathrm{~min}$ & \# Runs: 5 \\
\end{tabular} \\
\hline \multicolumn{5}{|r|}{ Chemist 3 - Batch 1} \\
\hline Sample \# & Opioid & Cath. & Cann. & $\begin{array}{c}\text { Controlled Substances Identified } \\
\end{array}$ \\
\hline 2 & & & & Not Analyzed - No Targeted Method for Methamphetamine \\
\hline 4 & $\mathrm{X}$ & & & $\begin{array}{c}\text { Fentanyl } \\
\text { Insufficient: (Tramadol / Mannitol) } \\
\end{array}$ \\
\hline 6 & & $\mathrm{X}$ & & MDMA \\
\hline 8 & $\mathrm{X}$ & & & Heroin \\
\hline 10 & & $\mathrm{X}$ & & 4-Ethylmethcathinone \\
\hline+ Control & $\mathrm{X}$ & $\mathrm{X}$ & & \begin{tabular}{l|l} 
Runtime: $127.5 \mathrm{~min}$ & \# Runs: 6 \\
\end{tabular} \\
\hline & & & & Chemist 3 - Batch 2 \\
\hline Sample \# & Opioid & Cath. & Cann. & Controlled Substances Identified \\
\hline 11 & & $\mathrm{X}$ & & Dibutylone \\
\hline 13 & & & $\mathrm{X}$ & FUB-AMB \\
\hline 15 & & & $\mathrm{X}$ & AB-FUBINACA 2-fluorobenzyl isomer \\
\hline 17 & & $\mathrm{X}$ & & Dibutylone \\
\hline 19 & $\mathrm{X}$ & & & Acetyl Fentanyl, Fentanyl, FIBF, Heroin \\
\hline+ Control & $\mathrm{X}$ & $\mathrm{X}$ & $\mathrm{X}$ & \begin{tabular}{l|l} 
Runtime: $128.5 \mathrm{~min}$ & \# Runs: 8 \\
\end{tabular} \\
\hline
\end{tabular}




\begin{tabular}{|c|c|c|c|c|}
\hline \multicolumn{5}{|r|}{ Chemist 3 - Batch 3} \\
\hline Sample \# & Opioid & Cath. & Cann. & Controlled Substances Identified \\
\hline 22 & $\mathrm{X}$ & & $\mathrm{X}$ & Fentanyl, XLR11 \\
\hline 24 & & & $\mathrm{X}$ & JWH-018 \\
\hline 26 & & $\mathrm{X}$ & & Eutylone \\
\hline 28 & & $\mathrm{X}$ & & 4-Methylethcathinone \\
\hline 30 & $\mathrm{X}$ & $\mathrm{X}$ & $\mathrm{X}$ & $\begin{array}{l}\text { Fentanyl, JWH-250 } \\
\end{array}$ \\
\hline + Control & $\mathrm{X}$ & $\mathrm{X}$ & $\mathrm{X}$ & \begin{tabular}{l|l} 
Runtime: $183 \mathrm{~min}$ & \\
\end{tabular} \\
\hline \multicolumn{5}{|r|}{ Chemist 3 - Batch 4} \\
\hline Sample \# & Opioid & Cath. & Cann. & Controlled Substances Identified \\
\hline 31 & $\mathrm{x}$ & & & Tramadol \\
\hline 33 & $\mathrm{X}$ & & & Acetyl Fentanyl, Fentanyl, FIBF, Heroin \\
\hline 35 & $\mathrm{X}$ & & & $\begin{array}{c}\text { Fentanyl } \\
\text { Insufficient: (Tramadol / Mannitol) }\end{array}$ \\
\hline 37 & $\mathrm{X}$ & & & Heroin \\
\hline 39 & $\mathrm{X}$ & & & Fentanyl \\
\hline+ Control & $\mathrm{X}$ & & & Runtime: $210 \mathrm{~min}$ \\
\hline \multicolumn{5}{|r|}{ Chemist 3 - Batch 5} \\
\hline Sample \# & Opioid & Cath. & Cann. & Controlled Substances Identified \\
\hline 42 & $\mathrm{x}$ & & & $\begin{array}{c}\text { Acetyl Fentanyl, Fentanyl, FIBF, Heroin } \\
\text { Insufficient: Cocaine (Not in Targeted Methods), Noscapine }\end{array}$ \\
\hline 44 & $\mathrm{X}$ & & & N-Methyl Cyclopropyl Norfentanyl \\
\hline 46 & & $\mathrm{X}$ & & 4-Methylethcathinone \\
\hline 48 & & $\mathrm{X}$ & & $\mathrm{N}$-Ethylpentylone \\
\hline 50 & & $\mathrm{X}$ & & $\alpha-P V P$ \\
\hline + Control & $\mathrm{X}$ & $\mathrm{X}$ & & Runtime: $135 \mathrm{~min}$ \\
\hline \multicolumn{5}{|r|}{ Chemist 4 - Batch 1} \\
\hline Sample \# & Opioid & Cath. & Cann. & $\begin{array}{c}\text { Controlled Substances Identified } \\
\end{array}$ \\
\hline 1 & & & & Not Analyzed - No Controlled Substances ID'ed in DART-MS \\
\hline 3 & $\mathrm{X}$ & $\bar{X}$ & & Heroin, MDMA \\
\hline 5 & & $\mathrm{X}$ & & MPHP \\
\hline 7 & & & & Not Analyzed - No Controlled Substances ID'ed in DART-MS \\
\hline 9 & $\mathrm{X}$ & & & N-Methyl Norfentanyl \\
\hline + Control & $\mathrm{X}$ & $\mathrm{X}$ & & \begin{tabular}{l|l} 
Runtime: $127.5 \mathrm{~min}$ & \\
\end{tabular} \\
\hline \multicolumn{5}{|r|}{ Chemist 4 - Batch 2} \\
\hline Sample \# & Opioid & Cath. & Cann. & Controlled Substances Identified \\
\hline 12 & $\mathrm{X}$ & $\mathrm{X}$ & & 4-Ethylmethcathinone, Fentanyl, 4-Me-a-Ethylaminopentiophenone \\
\hline 14 & $\mathrm{X}$ & & & Cyclopropyl Fentanyl, Heroin, Phenyl Fentanyl \\
\hline 16 & & & & Not Analyzed - No Controlled Substances ID'ed in DART-MS \\
\hline 18 & $\mathrm{X}$ & & & Acetyl Fentanyl, Fentanyl \\
\hline 20 & & & & Not Analyzed - No Controlled Substances ID'ed in DART-MS \\
\hline+ Control & $\mathrm{X}$ & $\mathrm{X}$ & & \begin{tabular}{c|c} 
Runtime: 155 min & \# Runs: 6 \\
\end{tabular} \\
\hline & & & & Chemist 4 - Batch 3 \\
\hline Sample \# & Opioid & Cath. & Cann. & $\begin{array}{c}\text { Controlled Substances Identified } \\
\end{array}$ \\
\hline 21 & & & & \multirow{2}{*}{$\begin{array}{c}\text { Not Analyzed - No Controlled Substances ID'ed in DART-MS } \\
\text { JWH-250 }\end{array}$} \\
\hline 23 & & & $\mathrm{X}$ & \\
\hline 25 & & $\mathrm{X}$ & & $\alpha-P V P$ \\
\hline 27 & & & & \multirow{2}{*}{$\begin{array}{c}\text { Not Analyzed - No Controlled Substances ID'ed in DART-MS } \\
\text { 5-F-AKB48, a-PBP }\end{array}$} \\
\hline 29 & & $\mathrm{X}$ & $\mathrm{X}$ & \\
\hline+ Control & & $\mathrm{X}$ & $\mathrm{X}$ & \begin{tabular}{l|l} 
Runtime: $58.5 \mathrm{~min}$ & \\
\end{tabular} \\
\hline & & & & Chemist 4 - Batch 4 \\
\hline Sample \# & Opioid & Cath. & Cann. & \multirow{2}{*}{ Controlled Substances Identified } \\
\hline 32 & & & $\mathrm{X}$ & \\
\hline 34 & & $\mathrm{X}$ & & $\begin{array}{c}\text { JWH-250 } \\
\text { Eutylone }\end{array}$ \\
\hline 36 & $\mathrm{X}$ & & & Methyl-AP-237 \\
\hline 38 & $\mathrm{X}$ & & $\mathrm{X}$ & a-Methyl Fentanyl \\
\hline 40 & $\mathrm{X}$ & $\mathrm{X}$ & & 4-Chloroethcathinone, Cyclopropyl Fentanyl \\
\hline+ Control & $\mathrm{X}$ & $\mathrm{X}$ & $\mathrm{X}$ & \begin{tabular}{l|l} 
Runtime: $198.5 \mathrm{~min}$ & \# Runs: 10
\end{tabular} \\
\hline
\end{tabular}




\begin{tabular}{|c|c|c|c|c|}
\hline \multicolumn{5}{|r|}{ Chemist 4 - Batch 5} \\
\hline Sample \# & Opioid & Cath. & Cann. & Controlled Substances Identified \\
\hline 41 & & & & Not Analyzed - No Controlled Substances ID'ed in DART-MS \\
\hline 43 & & $\mathrm{X}$ & & Methylone \\
\hline 45 & & & & Not Analyzed - No Controlled Substances ID'ed in DART-MS \\
\hline 47 & & $\mathrm{X}$ & $\mathrm{X}$ & JWH-018, 3,4-MDPV \\
\hline 49 & & & $\mathrm{X}$ & FUB-AMB \\
\hline + Control & & $\mathrm{X}$ & $\mathrm{X}$ & Runtime: $58.5 \mathrm{~min}$ \\
\hline
\end{tabular}

